
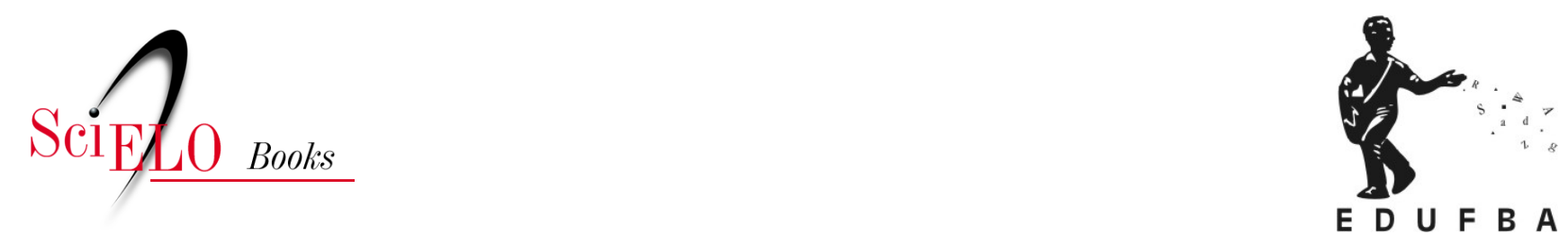

\title{
3 - A gênese da política nacional de aids no Brasil (1981-1989)
}

\author{
Sandra Garrido de Barros
}

\section{SciELO Books / SciELO Livros / SciELO Libros}

BARROS, S.G. A gênese da política nacional de aids no Brasil (1981-1989). In: Política Nacional de Aids: construção da resposta governamental à epidemia HIV/aids no Brasil [online]. Salvador: EDUFBA, 2018, pp. 42-120. ISBN 978-85-232-2030-3. https://doi.org/10.7476/9788523220303.0004.

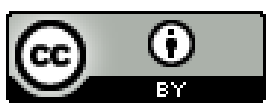

All the contents of this work, except where otherwise noted, is licensed under a Creative Commons Attribution 4.0 International license.

Todo o conteúdo deste trabalho, exceto quando houver ressalva, é publicado sob a licença Creative Commons Atribição 4.0. 



\section{A gênese da política nacional de aids no Brasil (1981-1989)}

A construção de um problema, seja ele um problema de saúde ou não, como um problema social, é um processo cuja evolução é determinada pelas alianças entre os diferentes grupos interessados, de modo a transformar interesses particulares em interesses coletivos. A construção da aids como um problema social, no Brasil, teve a participação de agentes de diversos campos e subespaços, uma correlação de forças que contribuiu para o surgimento de um espaço específico de organização da luta contra a aids (espaço aids), envolvendo agentes oriundos, principalmente - não exclusivamente-do espaço militante, do campo burocrático, do campo médico, do campo científico, do campo político e mesmo do campo religioso.

O Quadro 1 apresenta uma síntese dos principais fatos históricos relacionados ao espaço aids e à gênese e evolução da política nacional de controle da aids apresentados a seguir, buscando articulá-los ao contexto político-administrativo - presidente, ministro da saúde, dirigente da política -, bem como aos subespaços específicos - campos médico, científico e burocrático, espaço militante e imprensa - e evidencia a complexidade das relações estabelecidas ao interior do espaço aids no Brasil.

A abordagem desses diferentes subespaços tornou a análise bastante complexa, de modo que a apresentação dos fatos históricos concorrentes para a conformação do espaço aids e as lutas e disputas travadas no seu interior tentou seguir a ordem cronológica, mas também a sua relação com os subespaços analisados e a evolução da política de saúde estudada.

Uma vez que a mobilização em torno da doença e a capacidade de organização de uma resposta à epidemia estão relacionados à evolução do saber médico e das estratégias de intervenção possíveis (PINELL et al., 2002), para fins de análise, foram considerados quatro momentos da 
QUADRO 1-Síntese da conjuntura política e principais fatos históricos relacionados aos campos científico, burocrático, ao espaço militante e à imprensa com relação à implantação da política nacional de controle do HIV/aids no Brasil, 1981-2001

\begin{tabular}{|c|c|c|c|}
\hline \multicolumn{4}{|l|}{ Campo médico e científico } \\
\hline & $\begin{array}{l}\text { Diagnóstico dos primeiros } \\
\text { casos no Brasil }\end{array}$ & $\begin{array}{l}\text { Diagnóstico clínico, ainda não } \\
\text { havia teste sorológico } \\
\text { Laboratório de pesquisa em } \\
\text { Aids - Fiocruz }\end{array}$ & $\begin{array}{l}20^{\circ} \text { Congresso da Sociedade Brasileira de } \\
\text { Medicina Tropical (Salvador) - Aids não era } \\
\text { prioridade }\end{array}$ \\
\hline \multicolumn{4}{|l|}{ Campo burocrático } \\
\hline & & $\begin{array}{l}\text { Reunião MHS com João Yunes } \\
\text { Aids Informações Básicas (MS) } \\
\text { Programa Estadual de Aids } \\
\text { SES-SP }\end{array}$ & \\
\hline \multicolumn{4}{|l|}{ Espaço militante } \\
\hline $\begin{array}{l}\text { Notícias sobre a nova doença } \\
\text { vistas com descrédito pelos } \\
\text { grupos homossexuais }\end{array}$ & $\begin{array}{l}\text { Grupos homossexuais passam } \\
\text { a reforçar o discurso médico }\end{array}$ & $\begin{array}{l}\text { Reunião de militantes } \\
\text { homossexuais com Ricardo } \\
\text { Veronesi (USP) }\end{array}$ & \\
\hline \multicolumn{4}{|l|}{ Imprensa } \\
\hline $\begin{array}{l}\text { Primeiras notícias sobre } \\
\text { uma nova doença nos EUA } \\
\text { (peste gay) }\end{array}$ & & $\begin{array}{l}\text { Morte de Markito }(04 / 06) \\
\text { Primeiros casos noticiados na } \\
\text { imprensa }\end{array}$ & $\begin{array}{l}\text { Notícias ligadas aos estados, ocorrência de } \\
\text { casos, sem relação com o MS }\end{array}$ \\
\hline
\end{tabular}

\section{Waldyr Mendes Arcoverde}

Figueiredo 
Hélio e Peggy Pereira

trazem culturas de HIV

Adaptação da técnica de imunofluo-rescência p/ HIV
AZT

Isolamento do vírus no

Brasil
Implantação do

Laboratório Avançado de

Saúde Pública (Fiocruz-BA)

\begin{tabular}{|c|c|c|}
\hline Programa Estadual RJ & Maria Leide DNDS & 1a Campanha nacional \\
\hline $\begin{array}{l}\text { Portaria nº } 236(02 / 05) \\
\text { Treinamento para estados }\end{array}$ & $\begin{array}{l}\text { Lair Guerra PN Aids } \\
\text { Subtema da 8a CNS }\end{array}$ & CNCSIDA \\
\hline & \multicolumn{2}{|c|}{$\begin{array}{l}\text { Debates aids e } \\
\text { constituinte }\end{array}$} \\
\hline & $\begin{array}{l}\text { Comissão de } \\
\text { Assessoramento em aids }\end{array}$ & $\begin{array}{l}\text { Recomendações } p / \text { uso } \\
\text { do AZT }\end{array}$ \\
\hline
\end{tabular}

Lei Henfil (Lei 7649)

Divisão Nacional de Aids

Projeto Previna

Constituição Federal 1988
Aquisição de AZT por alguns estados

Redução de Danos em Santos e Salvador
Hemofílicos, talassêmicos

Fundação

GAPA-SP

Primeiro cartaz de

prevenção à aids

\section{Aids era assunto frequente} na imprensa

\section{Morte de Henfil (04/01) Morte de Lauro Corona}

Lair Guerra

\begin{tabular}{c|ccc} 
Carlos Sant'Anna & Roberto Santos & Luiz Carlos Borges da Silveira & Seigo Tsuzuki \\
Sarney &
\end{tabular}

1985 
QUADRO 1-Síntese da conjuntura política e principais fatos históricos relacionados aos campos científico, burocrático, ao espaço militante e à imprensa com relação à implantação da política nacional de controle do HIV/aids no Brasil, 1981-2001

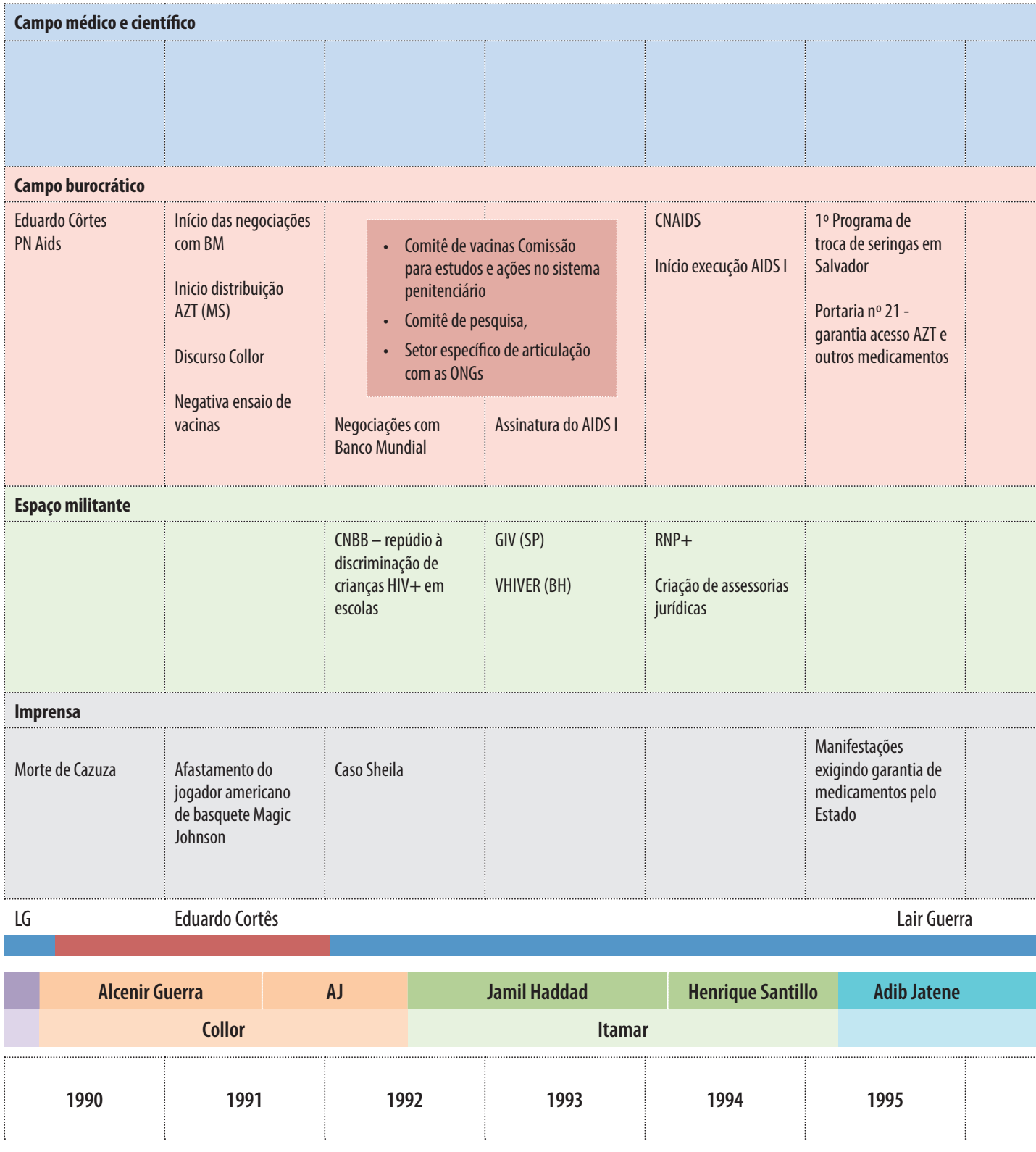

Fonte: Elaborado pela autora. 
XI Conferência

Internacional de Aids

(Vancouver)

Terapia combinada

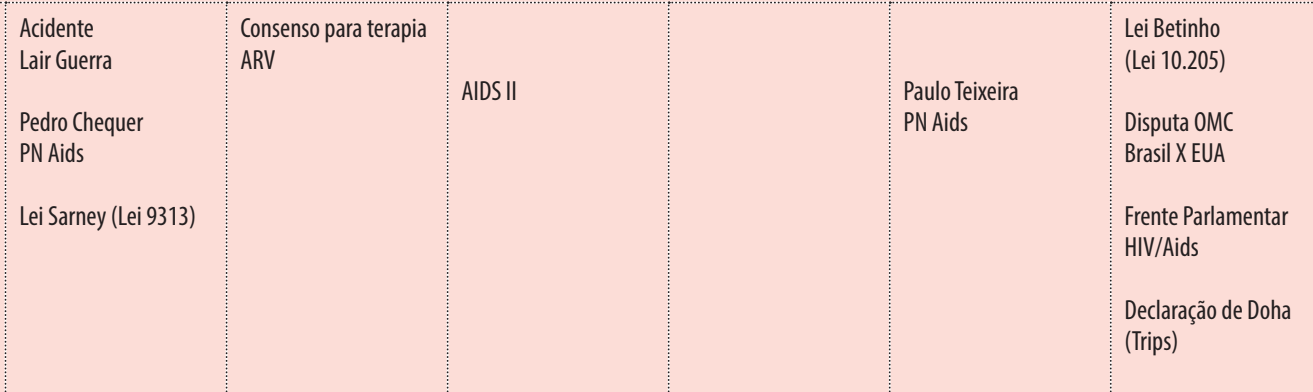

Movimento Patrocine a Vida

Ações judiciais terapia combinada

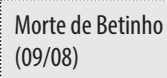

\section{José Serra}

FHC 
política nacional de controle da aids, relacionando os principais grupos atingidos, as ações prioritárias e a evolução do saber médico. (Quadro 2)

QUADRO 2 - Momentos da política nacional de controle da aids, principais grupos atingidos, ações prioritárias e sua relação com o saber médico, 1981-2001

\begin{tabular}{|c|c|c|c|c|}
\hline Período & Principais grupos atingidos* & Saber médico & Política de luta contra a aids & Ações prioritárias \\
\hline 1981-1984 & Homossexuais & $\begin{array}{l}\text { Descoberta do vírus } \\
\text { Teste sorológico }\end{array}$ & $\begin{array}{l}\text { Governo federal não possui } \\
\text { uma política específica }\end{array}$ & Iniciativas estaduais \\
\hline 1985-1989 & $\begin{array}{l}\text { Homossexuais, hemofílicos e } \\
\text { outros receptores de sangue e } \\
\text { hemoderivados }\end{array}$ & AZT & $\begin{array}{l}\text { Surgimento de uma política } \\
\text { nacional }\end{array}$ & $\begin{array}{l}\text { Ações de vigilância e } \\
\text { educação em saúde }\end{array}$ \\
\hline 1990-1996 & $\begin{array}{l}\text { Usuários de drogas injetáveis, } \\
\text { heterossexuais }\end{array}$ & $\begin{array}{l}\text { Realização de ensaios } \\
\text { para estudos de } \\
\text { vacinas no país } \\
\text { Terapia combinada } \\
\text { (controle da doença, } \\
\text { aumento da } \\
\text { sobrevida) }\end{array}$ & $\begin{array}{l}\text { Consolidação da política } \\
\text { nacional }\end{array}$ & $\begin{array}{l}\text { Distribuição de } \\
\text { medicamentos, } \\
1{ }^{\circ} \text { acordo de empréstimo, } \\
\text { financiamento ONGs }\end{array}$ \\
\hline 1997-2001 & $\begin{array}{l}\text { Feminização** } \\
\text { Envelhecimento } \\
\text { Interiorização } \\
\text { Pauperização } \\
\text { Aumento da sobrevida }\end{array}$ & $\begin{array}{l}\text { Novos medicamentos } \\
\text { (inibidores da } \\
\text { protease), redução } \\
\text { de efeitos colaterais, } \\
\text { controle da doença }\end{array}$ & $\begin{array}{l}\text { Apogeu da política nacional: } \\
\text { redução de indicadores } \\
\text { de morbimortalidade } \\
\text { (estabilização da epidemia) } \\
\text { e reconhecimento internacional }\end{array}$ & $\begin{array}{l}\text { Sustentabilidade da } \\
\text { estratégia do acesso } \\
\text { universal }\end{array}$ \\
\hline
\end{tabular}

Fonte: Elaborado pela autora.

Notas: *Fonte: Boletim Epidemiológico Aids (1987a, 1987b, 1988a, 1988b, 1990, 2001), Boletim Epidemiológico DST-Aids (1987c), Boletim Epidemiológico Aids/DST (2009, 2011), Boletim Epidemiológico HIV/aids (2014, 2015).

** Razão entre sexos no período de 1980-1990 foi de 6,5:1, e no período de 1991-2001 foi 2,4:1

Os dois primeiros momentos, que abrangem o período de 1981 a 1989, correspondem ao processo de conformação do espaço aids no Brasil, à gênese da resposta governamental no âmbito federal e ao desenvolvimento inicial da política; e são tratados nesse capítulo. Os dois momentos seguintes estão relacionados à evolução e consolidação da política nacional e serão apresentados no capítulo 4.

\section{A conformação do espaço aids no Brasil (1981-1984)}

A epidemia da aids chegou ao Brasil no início dos anos 1980, quando ainda não existia uma resposta terapêutica eficaz. O final da década de 1970 e início dos anos 1980 foi marcado pelo processo de "abertura” política e redemocratização do país, culminando com a anistia política dos exilados em 1979, na realização de eleições democráticas nos estados em 1982, 
na mobilização por eleições diretas para a presidência da república e na eleição indireta do primeiro governo federal democrático após o período de ditadura militar no início de 1985. (MACRAE, 1990) Essas condições permitiram a retomada da luta pelos direitos políticos e a constituição de um movimento social mais ativo nesse período, marcado inclusive pelo surgimento das organizações não governamentais, ${ }^{11}$ para o que contribuíram os retornados do exílio após a anistia, bem como outros que viajavam frequentemente ao exterior e aqueles relacionados a organizações como Ação Católica, ${ }^{12}$ Ação Popular $^{13}$ (AP) e Movimento de Educação de Base (MEB). (LANDIM, 2002)

A aids chegou ao país em um momento de expansão do gueto gay ${ }^{14}$ (SILVA, 1986) Desde 1976 já existiam tentativas de organização de um congresso de homossexuais no Rio de Janeiro e de formação de um grupo de discussão homossexual, mas só depois de uma visita do editor do jornal americano Gay Sunshine, Winston Leyland, em 1977 ao Brasil, que um

11 " $[. .$.$] categoria [...] usada para designar subconjuntos de organizações (como ambientalistas,$ de negros, mulheres, povos indígenas, portadores de HIV, etc.) que, embora variadas, ocupam posições análogas no campo político e social e possuem características comuns, como por exemplo: são de origem recente e ligadas em grande parte a movimentos sociais, compreendendo-se como tal também os relacionados à criação de novas identidades e à defesa de direitos específicos ou difusos; têm portanto determinados horizontes comuns no centro dos seus ideários, como a expansão de valores democráticos, de direitos civis, da cidadania; inserem-se marcadamente em redes de relações internacionalizadas, onde a questão do financiamento está de alguma forma presente." (LANDIM, 2002, p. 220)

12 Movimento controlado pela igreja católica que compreendia quatro grupos: Homens da Ação Católica e Liga Feminina de Ação Católica, para os maiores de 30 anos ou casados de qualquer idade; e Juventude Católica Brasileira e Juventude Feminina Católica, para os jovens de 14 a 30 anos. A Juventude Católica compreendia a Juventude Estudantil Católica (JEC), para os jovens secundaristas, a Juventude Universitária Católica (JUC), para os universitários, e a Juventude Operária Católica (JOC), para os jovens operários. Em 1962, militantes da JUC e da JEC criaram a Ação Popular. (KORNIS, 2001)

13 Movimento político clandestino resultado da atuação dos militantes estudantis da Juventude Estudantil Católica (JEC) e da Juventude Universitária Católica (JUC). Criado em 1962, foi um dos mais importantes movimentos de resistência ao regime militar durante a década de 1960. Em 1967 mudou sua sigla para APML (Ação Popular Marxista-Lenista) e terminou com sua incorporação ao Partido Comunista do Brasil (PC do B).

14 O termo gueto era usado entre os homossexuais para denominar locais de encontro, como bares, boates, saunas, parques, restaurantes frequentados por homossexuais de forma exclusiva ou quase exclusiva, ou para designar ruas ou locais específicos. (SILVA, 1986) 
grupo de intelectuais homossexuais fundou o jornal Lampião da Esquina, principal meio de comunicação homossexual no Brasil até 1981, quando foi editado seu último número.

Foi uma discussão sobre homossexualidade na Semana da Convergência Socialista, promovida pela Revista Versus, em 1977, que motivou João Silvério Trevisan, escritor e jornalista, e outros homossexuais ligados ao Lampião da Esquina a realizarem reuniões semanais, das quais resultou a formação do "Somos - Grupo de Afirmação Homossexual" 15 (Somos), o primeiro grupo gay do Brasil, em São Paulo. (FACCHINI, 2003; MACRAE, 1990) Foram também fundadores do Somos o antropólogo inglês Peter Fry, professor da Universidade de Campinas (Unicamp), Darcy Penteado, cenógrafo, autor teatral e um dos idealizadores do primeiro cartaz de prevenção da aids no Brasil, e o cineasta belga Jean Claude Bernadet.

A partir da criação do Somos, em 1978, houve uma proliferação de grupos de militância homossexual que lutavam pelos direitos civis dessa minoria por todo o país. (FACCHINI, 2003; MACRAE, 1990)

No Brasil, não existia uma legislação homofóbica a ser combatida como nos EUA e na França, por exemplo, mas a homossexualidade constava na lista de doenças do Instituto Nacional de Assistência Médica e Previdência Social (Inamps), o que tornava a relação com o campo médico conflituosa. (FACCHINI, 2003; MACRAE, 1990) Apesar da homossexualidade não ser crime no Brasil, a violência contra homossexuais, inclusive por parte do aparato de violência física do Estado, sempre esteve presente, sendo esta inclusive uma das principais lutas do movimento gay. (MACRAE, 1990; SILVA, 1986) Mas foram as divergências internas aos próprios grupos, resultantes do seu crescimento numérico, e a incapacidade de convivência de diferentes posições políticas entre aqueles que desejavam uma atuação mais voltada para a garantia de direitos dos homossexuais e os que propunham um engajamento político mais amplo, que levou à ruptura do Somos após o $1^{\circ}$ de maio de 1980, um “racha” no

15 O nome Somos - Grupo de Afirmação Homossexual, era uma homenagem à publicação da Frente de Liberação Homossexual Argentina, o primeiro grupo pelos direitos gays na América do Sul, que surgiu em Buenos Aires, em 1971 e foi extinta pela ditadura militar daquele país em março de 1976. (GREEN et al., 2003) 
jargão político-associativo. Dessa ruptura surgiu o Grupo Outra Coisa Ação Homossexualista e o Grupo Lésbico-feminista. (MACRAE, 1990) O Somos ainda continuou, mas, com dificuldades financeiras e dificuldades em conseguir novos membros, dissolveu-se por volta de 1983.

Uma primeira onda do movimento homossexual no Brasil teria ocorrido até 1983, coincidindo com a emergência da epidemia da aids no país, caracterizada por grupos com caráter mais comunitário e de convivência. O surgimento da epidemia da aids teria levado a transformações no movimento gay, levando a uma desmobilização em relação às propostas de liberação sexual e também devido ao envolvimento de lideranças homossexuais na luta contra a epidemia. (FACCHINI, 2003)

O Lampião da Esquina teve seu último número publicado em junho de 1981 e não chegou a mencionar a nova doença que começava a aparecer nos EUA e que a imprensa começava a noticiar no Brasil. ${ }^{16} \mathrm{O}$ fim do Lampião da Esquina ${ }^{17}$ foi outro fato que contribuiu para a desmobilização do movimento, que perdeu seu principal meio de comunicação. Essa desmobilização do movimento homossexual resultou na redução do número de grupos de 22 em 1980, para apenas 8 em 1988. Um novo crescimento do número de grupos aconteceria na década de 1990, na segunda onda do movimento gay, com grupos de caráter mais formal, aos quais a principal causa era a garantia dos direitos homossexuais e a luta contra a discriminação e violência. (FACCHINI, 2003)

As primeiras notícias sobre a nova doença, que matava rapidamente, acometia principalmente a população homossexual e se manifestava principalmente por infecções severas e pelo sarcoma de Kaposi, tinham tratamento jornalístico de um problema estrangeiro e contribuíram para a visão de uma doença de homossexuais, designando-a inicialmente de peste gay. (BARATA, 2006; SILVA, 1986) Mas, a partir daquele momento, a imprensa também assumiu um importante papel na divulgação da doença e na construção social do problema. (BARATA, 2006)

16 Acervo do jornal Lampião da esquina, 1978-1981.

17 Sobre o fim do jornal Lampião da esquina, Facchini (2003), analisa como natural que no período democrático um meio de comunicação criado para lutar contra a ditadura, com o fim da censura, também tivesse se esgotado. 
As notícias divulgadas nos meios de comunicação eram vistas com descrédito pela comunidade homossexual. A crença era que se tratava de mais uma tentativa dos médicos para atingir os homossexuais, uma forma de "usar um argumento médico para tentar fazer um retrocesso" (E8) $)^{18}$ das conquistas do movimento homossexual. (PERLONGHER, 1987) Esse era o posicionamento do grupo Moléculas Malucas ${ }^{19}$ (E8), liderado por Néstor Perlongher, professor da Unicamp e ex-militante do movimento de liberação homossexual argentino. Assim, percebia-se inicialmente uma negação do problema, exemplificada também pela primeira notícia que apareceu no boletim do Grupo Gay da Bahia (GGB), em abril de 1982, com o título “Uma doença de homossexuais??????. A matéria criticava a revista Manchete pela divulgação de uma notícia da Time Magazine considerando que se tratava de uma "grande balela" e que "toda teoria médica que parte da premissa que somos 'promíscuos' não merece confiança”. (MOTT, 2011, p. 33)

Esse posicionamento questionador em relação ao campo médico era resultado da relação histórica dos médicos com a homossexualidade, considerada como doença mental. (FATAL, 1988; MOTT, 1987) Contudo, quando o problema foi reconhecido pelo grupo, eles assumiram uma postura de reforço do discurso médico. (E2O) ${ }^{20}$ (MOTT, 1987) Em dezembro daquele ano, o discurso no Boletim do GGB já havia mudado, alertando para os sintomas da nova doença, denominada "peste rosa", referindo-se à matéria da revista Manchete e orientando aqueles que apresentassem os sintomas a procurarem o GGB. (MOTT, 2011)

Essa mudança no discurso está provavelmente relacionada aos relatos de homossexuais brasileiros que viajavam para os EUA, e que traziam notícias do pavor e das mortes (E8), bem como notícias recebidas através dos grupos estrangeiros, em especial americanos (E2O), e à ameaça representada pela epidemia ao comércio gay que começava a se desenvolver

18 Entrevista concedida por E8, antropólogo, professor universitário e ex-militante do Somos, em Salvador, em 16 de maio de 2011.

19 O termo foi adotado em referência à revolução molecular de Guattari. 
(MACRAE, 1990; PERLONGHER, 1987; SILVA, 1986), como evidenciado nas falas dos militantes:

[...] eu fui convidado para fazer uma reportagem nos Estados Unidos e passei uma semana em Nova Iorque [...] De repente, eu chego lá e todos estão apavorados. Eu fiqueisabendo de gente morrendo feito mosca. [...] Eu volteipara o Brasile os meus amigos e antigos companheiros militantes, quase ninguém acreditava. (E8)

[...] eu percebi que nem a política do avestruz, nem essa política da negação da doença ou apenas da demonização do HIV como uma doença, como uma pandemia criada em laboratório, isso não ia levar a nada. Então, eu considerei que era fundamental a participação dos movimentos homossexuais nesse esforço coletivo contra a epidemia. (E2O)

O “caso um" de aids no país começou a apresentar os sintomas de emagrecimento e sinais de fraqueza em abril de 1980, tendo ido a óbito no dia 18 de março de 1981, no Hospital São Paulo, na Vila Mariana, na cidade de São Paulo. O esclarecimento da causa da morte só aconteceu cinco anos depois, na dissertação de mestrado do médico Antônio Luiz de Arruda Mattos, que constatou se tratar de aids. (NATALI, 1990) O registro desse caso pelo Ministério da Saúde só ocorreu em 1988. (BOLETIM..., 1988b) Esse fato evidencia que o vírus já circulava no país no final da década de 1970, como enfatizado por Lair Guerra no texto Aids - A face da discriminação, no Boletim Epidemiológico Aids, ano II, n. 5, de 1988.

Apesar do importante papel assumido pela imprensa na veiculação das primeiras notícias sobre a nova doença, só em 1983 os primeiros casos brasileiros foram noticiados nos jornais. Após a leitura de uma reportagem da jornalista Letânia Menezes ${ }^{21}$ na qual era afirmado que no Brasil ainda não existiam casos da doença, a médica Valéria Petri, ${ }^{22}$ uma jovem

21 Jornalista gaúcha que começou a carreira no Jornal Zero hora de Porto Alegre, tendo trabalhado também no Globo e na revista Isto É. Foi a primeira a publicar em 1983 uma matéria sobre aids e dedicou-se a fazer matérias exclusivamente sobre esse assunto inicialmente na IstoÉ e posteriormente na Folha de S. Paulo.

22 E31, médica dermatologista, filha de imigrantes italianos, que havia terminado de concluir o doutorado e estava trabalhando com o professor Aurélio Ancona Lopes na Escola Paulista de 
dermatologista da Escola Paulista de Medicina - atual Unifesp -, contatou a jornalista da revista Isto $E$.

Eu não tinha muita convicção de que precisasse alertar o público. Não sabia a utilidade disso, mas eu não me conformava com o erro, com a informação equivocada. [...] Eu achava que precisava corrigir a matéria errada. (E31)

Os casos haviam sido identificados em setembro de 1982 e janeiro de 1983, na cidade de São Paulo. Eram dois homens, um de 32, outro de 30 anos, homossexuais, que apresentavam lesões de pele (sarcoma de Kaposi) e haviam viajado recentemente aos EUA (E31). (ABBADE; BAIÃO, 2010; FRANÇA, 2008; GUERRA, 1993; MARQUES, 2003)

A dermatologia desempenhou importante papel no diagnóstico dos primeiros casos, justamente por conta do sarcoma de Kaposi, uma lesão de pele pouco comum em jovens, que se mostrava presente na maioria dos casos. Naquele momento, ainda não havia testes sorológicos. O diagnóstico era clínico, associado ao diagnóstico histopatológico de sarcoma de Kaposi e às características do paciente - homem, homossexual, 30-32 anos, que viveu em Nova Iorque -, ainda que a lesão não fosse típica. (E31)

A divulgação dos casos causou alguns incômodos, talvez por se tratar de uma mulher jovem, dermatologista, recém-doutora, ainda uma recém -ingressa no campo científico e no campo médico; dessa forma, a veracidade do diagnóstico foi questionada por alguns médicos infectologistas.

Mas foi muito difícil lidar com isso porque além de não haver perspectiva nenhuma de tratamento, ainda era tudo muito assustador, havia ainda colegas que insistiam em que eu estava mentindo. (E31)

A Folha de São Paulo, um dos principais jornais do país, só mencionou os dois casos em junho de 1983, quase um ano após a detecção. ${ }^{23} \mathrm{Na}$ literatura médica brasileira, a Revista Paulista de Medicina apresentou os

Medicina e no seu consultório particular. Concedeu entrevista em São Paulo, em 20 de junho de 2011.

23 Ver Rocha (1983). 
primeiros relatos de casos no número de julho/agosto de 1983. Dois casos ocorridos no estado de São Paulo: um identificado em julho de 1982, em Campinas, na Disciplina de Doenças Transmissíveis da Faculdade de Ciências Médicas da Unicamp, que foi a óbito cinco dias após a internação (GONÇALES JÚNIOR et al., 1983); outro descrito como primeiro caso autóctone do país por docentes da Clínica de Doenças Infecciosas e Parasitárias da Faculdade de Medicina da Universidade de São Paulo (USP) e da disciplina de Imunologia da Escola Paulista de Medicina (EPM). (AMATO NETO et al., 1983)

A sigla referente ao nome da doença em português, Síndrome da Imunodeficiência Adquirida (Sida), não emplacou no Brasil, prevalecendo o uso da sigla em inglês, Autoimmune Deficiency Syndrome (AIDS). Desde as primeiras notícias veiculadas na mídia, a imprensa e os médicos incorporaram o termo em inglês, em uma clara influência da língua inglesa, que pode ser classificado como um estrangeirismo. Durante algum tempo, o Ministério da Saúde tentou usar o termo Sida, presente em diversos documentos, mas sempre associado ao termo aids. Em 1997, uma reportagem da revista Veja levantava o porquê do termo Sida não ser adotado no país e considerando-se mirabolante a explicação de o termo não ser usado devido às piadas que faziam com as Aparecidas cujo apelido Cida era muito comum, além da possível referência à Santa Padroeira do Brasil, Nossa Senhora da Conceição Aparecida. (SCALZO, 1997) Ainda que o uso do termo aids tenha sido preferido pela imprensa e pelos médicos desde as primeiras notícias, segundo um dos entrevistados, essa discussão acerca do uso dos termos aids ou Sida teria de fato existido, tendo inclusive ocorrido uma reunião no Ministério da Saúde para decidir que termo usar. (E11) 24 Ou seja, houve uma racionalização para justificar a submissão aos EUA, tanto no campo científico como no campo cultural.

[...] naquela época eu era quase que estagiário, e eu participei das reuniões na criação do programa. E me lembro que o Brasilé o único pais do mundo que não chama Sida. É o único pais da América Latina que não chama Sida. Que era... que em agosto de 2011. 
português seria Síndrome da Imunodeficiência Adquirida e a gente chama aids. Eu estava presente na reunião principal onde se decidiu que no Brasil não ia se chamar Sida. Por causa das Aparecidas, que são Cidas.

Entrevistador: Éverdade essa história?

É verdade. História verdadeira. Assim, pra não estigmatizar todas as Aparecidas que se chamavam Cida. É por isso que ficou aids. (E11)

Em 1983, começaram também a surgir notícias relacionadas ao uso de interferon como tratamento para a aids. ${ }^{25} \mathrm{O}$ médico Ricardo Veronesi, ${ }^{26}$ um dos responsáveis pela aplicação do interferon como tratamento para aids no Brasil, iniciativa de uma empresa farmacêutica suíça que fornecia o medicamento gratuitamente, realizou uma reunião por volta de março ou abril de 1983, buscando uma maior aproximação com o principal grupo acometido pela epidemia, evento que reuniu diversos militantes do movimento homossexual, entre eles componentes do Grupo Somos que não se encontravam desde o "racha" do grupo, alertando-os para a necessidade de uma resposta do Estado (E8). (HC INICIA..., 1983)

São Paulo tinha naquele momento em seu primeiro governo estadual eleito pelo voto popular, ainda durante o período da ditadura militar, em 1982. O governador era Franco Montoro, ${ }^{27}$ do Partido do Movimento

25 C.. INTERFERON..., 1983; CONGRESSO..., 1983.

26 Médico, Professor da Faculdade de Medicina de São Paulo, fundador da Sociedade Brasileira de Infectologia, criada justamente porque junto com o prof. Paulo Augusto Ayrosa Galvão, Veronesi considerava que havia a necessidade de uma especialidade que englobasse de forma mais abrangente as doenças infecciosas e parasitárias, haja vista que as epidemias hospitalares e a pandemia de HIV/aids não cabiam na Medicina Tropical, que tratava principalmente das questões de saúde pública, e que não estavam relacionadas apenas aos trópicos. (SBI, 2005)

27 Bacharel em Direito pela USP (1938), Montoro foi professor universitário da PUC-SP (19381940), procurador do estado de São Paulo (1940-1950), vereador do município de São Paulo pelo Partido Democrata Cristão (PDC) em 1950, deputado estadual em 1954, e deputado federal em 1958, 1962 e 1966, esta última já pelo MDB. Foi Ministro do Trabalho e Previdência Social (1961-1962) durante o governo parlamentarista. Com a instauração do bipartidarismo no Brasil, ingressou no oposicionista Movimento Democrático Brasileiro (MDB). Foi senador em 1970 e governador do estado de São Paulo em 1982. Foi sua a iniciativa de realização do primeiro comício pelas eleições diretas para presidente da república em São Paulo no ano de 1984. (MAYER; MONTEIRO; ALDÉ, 2001) 
Democrático Brasileiro (PMDB), que congregava uma frente de partidos clandestinos como Partido Comunista Brasileiro (PCB) e Partido Comunista do Brasil (PC do B), e que se opunha à ditadura. Na Secretaria de Saúde do Estado de São Paulo (SES-SP), João Yunes ${ }^{28}$ foi nomeado para o cargo de secretário. Naquele período, a SES-SP já contava com um sistema de saúde organizado e um quadro técnico qualificado, haja vista a reforma administrativa do final da década de 1960, denominada Reforma Leser, que promoveu a integração dos serviços no nível local, tendo os centros de saúde como eixo; a descentralização executiva com a criação de distritos sanitários; a elaboração de normas técnicas; a implantação de sistemas de planejamento, epidemiologia, estatística; a qualificação profissional e a criação de carreiras específicas no âmbito da Saúde Pública, com regime de dedicação exclusiva e boas condições de trabalho; bem como a criação de uma superintendência de saneamento ambiental. (RIBEIRO, 2008)

A emergência da política de controle da aids no estado de São Paulo ${ }^{29}$ ocorreu a partir da reunião de um grupo de militantes do movimento pelos direitos dos homossexuais com o Secretário da Saúde de São Paulo, João Yunes. (BARBOZA, 2006; GUERRA, 1993; MARQUES, 2003; TEIXEIRA, 1997) Essa audiência foi agendada por Darcy Penteado, motivada pela reunião com o médico Ricardo Veronesi, pela notícia dos primeiros casos de aids identificados no Brasil e diante das notícias trazidas por pessoas que viajavam aos EUA. (E8; E26; E31)

Foi de maneira bem simples, uma demanda iniciada por pessoas que tinham de uma ou outra maneira, com uma ou outra intensidade, história de participação no movimento pelos direitos dos homossexuais. [...] e cobraram da secretaria como, digamos, um representante da comunidade homossexual, providências,

Médico graduado pela USP em 1963, concluiu o Mestrado na Escola de Saúde Pública da Universidade de Michigan, Ann Arbor, Estados Unidos, em 1967. Especializou-se em Pediatria em 1970. Em 1971 concluiu o Doutorado na Faculdade de Medicina da USP. Além de Secretário da Saúde de São Paulo (1983-1987), João Yunes assumiu cargos no Ministério da Saúde do Brasil (1975-1979; 1998-2000), na OPAS (1987-1998) e foi diretor da Escola de Saúde Pública da USP. (2001-2002) consultar: Guerra (1993); Silva (1986); Barboza (2006) e França (2008). 
orientações, informações a respeito da epidemia diante do pânico que se criava no meio homossexual. (E26) 30

Tratava-se de umgrupo de ex-integrantes doSomos e dojornal Lampião da Esquina, composto por Darcy Penteado, Edward MacRae, Jean Claude Bernadet e João Silvério Trevisan, acompanhados da médica Valéria Petri. O grupo solicitava um pronunciamento da SES-SP sobre a aids e providências no atendimento a futuros casos. (E8; E26; E31) Após esse encontro, começou o movimento na SES-SP para a criação do Programa de Aids. Isso ocorreu através de um grupo de trabalho composto por técnicos - médicos sanitaristas, infectologistas, especialistas na área de laboratório e na área social - de diversos setores da secretaria, coordenado pela divisão de Hansenologia e Dermatologia Sanitária, que estava estruturando um serviço de doenças sexualmente transmissíveis (TEIXEIRA, 1997) e que tinha à sua frente o dermatologista sanitário Paulo Roberto Teixeira, coincidentemente, ex-integrante do Somos. (E26)

Assim, os principais fatos que contribuíram para a concretização do Programa de Aids na SES-SP, conforme já destacado em outros estudos, ${ }^{31}$ foram a existência de casos já diagnosticados em São Paulo; a demanda de um grupo de militantes homossexuais reforçado pelo apoio da médica da Escola Paulista de Medicina, Valéria Petri; e as condições políticas - um governo democrático, no qual militantes da reforma sanitária assumiram posições estratégicas. Acrescente-se a estes o pavor suscitado pela epidemia e o grupo social atingido, não apenas um grupo organizado, mas de classe social elevada, composta por intelectuais de diferentes áreas e com importante capital social; o fato de o Estado já dispor de um sistema de saúde organizado e um quadro técnico qualificado desde a década de 1960, inclusive com a carreira de sanitarista, resultado da Reforma Leser; e a existência de um diretor sanitarista e ex-integrante do movimento homossexual, ou seja, uma pessoa não apenas acostumada a trabalhar com pessoas estigmatizadas, mas também integrante de um grupo minoritário,

Entrevista concedida por E26, médico e gestor, em São Paulo, em 3 de maio de 2011. 
o que lhe conferia disposição para trabalhar com populações marginalizadas, fossem os portadores de hanseníase ou os "transgressores da moral e dos bons costumes" como eram vistos os portadores de HIV/aids, homossexuais, usuários de drogas injetáveis e profissionais do sexo, à exceção dos hemofílicos, vistos como vítimas da irresponsabilidade alheia.

[...] quando havia uma insinuação de que eu estava promovendo isso porque eu era homossexual, eu nunca me envolvi nessa discussão, nunca gastei energia nessa discussão. E quando eventualmente eu fazia, me lembrava e lembrava as pessoas do envolvimento eproblemas que tinha por trabalhar com hanseníase [...] Nós estamos falando de um grupo de cidadãos historicamente estigmatizados, discriminados e o primeiro responsável por defender e apoiar essa comunidade éo Estado. (E26)

A partir da criação do Programa Estadual de São Paulo, começou a se estabelecer um espaço de articulação entre agentes de diferentes campos e espaços - campo médico, campo científico, campo burocrático, campo político e espaço militante - preocupados em organizar a resposta à epidemia da aids, o espaço aids, conforme definido por Pinell e colaboradores (2002).

O grupo Outra Coisa/Ação Homossexualista, uma das dissidências do Somos, tornou-se um importante parceiro do Programa de Aids da SES-SP, sendo um intermediário na comunicação com a comunidade gay. O grupo era responsável por distribuir folhetos explicativos sobre os sintomas da aids e como agir em bares, restaurantes, saunas, ruas e praças públicas frequentadas pela comunidade homossexual. A elaboração do primeiro material foi supervisionada pelos médicos Ricardo Veronesi, da USP, e Valéria Petri, da Escola Paulista de Medicina. O Instituto Adolfo Lutz ficou responsável pela realização de testes gratuitos, e a seção de Dermatologia da Escola Paulista de Medicina e o serviço de moléstias infecciosas do Hospital das Clínicas (USP) ficaram definidos como locais para atendimento. (ROCHA, 1983)

Ainda que nesse momento o Ministério da Saúde não estivesse atento à epidemia, também houve envolvimento de instituições federais de ensino e/ou pesquisa, por iniciativa dos próprios docentes/pesquisadores. Assim, também em 1983, foi criado o Laboratório de Pesquisa em Aids 
na Fundação Osvaldo Cruz (Fiocruz), no Rio de Janeiro, iniciativa de Bernardo Galvão de Castro Filho, médico, coordenador do laboratório, com mestrado em Patologia Humana (UFBA) e Doutorado em Imunologia, em Genebra, na Suíça, e de Claudio Ribeiro, médico com doutorado em imuno-hematologia na França. O laboratório surgiu do Laboratório de Imunologia Parasitária da Fiocruz no Programa de Pesquisas em Doenças Tropicais, que mais tarde se transformou no Departamento de Imunologia do Instituto Oswaldo Cruz..$^{32} \mathrm{~A}$ partir do contato com um paciente de aids, Galvão e Claudio Ribeiro viram a necessidade de estudar a doença e conseguiram aprovar um projeto junto ao CNPq para estudar casos de aids no Brasil, com o objetivo de verificar se as alterações imunobiológicas eram semelhantes às encontradas em pacientes de outros países. (MOURA, 2005) Esta pode ter sido uma oportunidade para os dois recém-doutores criarem sua própria linha de pesquisa, diferente daquela da imunopatologia, com ênfase em chagas e esquistossomose.

Além disso, a médica Valéria Petri, na Escola Paulista de Medicina, assim como ocorreu em outras escolas federais e estaduais, iniciava assistência aos primeiros pacientes identificados, mesmo que sem muitas possibilidades de tratamento. (E31)

Desta forma, o espaço aids, desde seus primórdios, envolveu importantes instituições universitárias, como a Universidade de São Paulo e a Fiocruz, às quais estavam vinculados alguns agentes.

Os principais agentes envolvidos no início da luta contra a epidemia no país ou pertenciam ao principal "grupo de risco" (homens homossexuais) ou eram profissionais da área da saúde, em especial médicos - dermatologistas, infectologistas, patologistas ou imunologistas- que

O projeto foi desenvolvido a partir de 1978, quando Bernardo Galvão havia acabado de retornar de Genebra, onde foi fazer o Doutorado em Imunologia (1974-1977), orientado por Paul Henri Lambert (que entre 1975 e 1987 liderava o Immunology Research and Training Programme da OMS e o Laboratório de Pesquisas da OMS na Universidade de Genebra e Lausanne, onde Galvão trabalhou durante os anos que ficou em Genebra). O projeto inicial pedia, por sugestão de Paul Henri, colaboração de Genebra para a organização do Laboratório de Imunologia Parasitária da Fiocruz. Em 1981, o projeto final foi aprovado. Esse laboratório, segundo Galvão, tornou-se "foco de atração para recém-doutores que estavam retornando ao país" (Entrevista concedida por E4, médico patologista e pesquisador da Fiocruz, em Salvador, em 12 de julho de 2011). 
tiveram contato com a epidemia no exercício profissional e eram, praticamente todos, servidores públicos, estaduais e/ou federais. Verificou-se que os servidores federais, no seu discurso destacavam que se tratava, de alguma forma, de uma iniciativa individual, mas representando o Estado, por se considerarem agentes do Estado.

Na reunião como Yunes foi imediata a coisa. Ele disse: 'vocêna Escola Paulista faz o que você puder e nós vamos fazer na secretaria o que a gente puder.' Quer dizer que no nivel federal eu estava me mexendo. (E31)

[Entrevistador:] Então eram ações individuais, sem interferência (ou apoio) do governo?

Galvão [Bernardo Galvão Castro Filho]: Algumas passaram pelo Estado porque os pesquisadores representavam o Estado. (BROTAS, 2007)

A emergência do Programa Estadual de Aids da SES-SP conformou, assim, um espaço específico de organização da luta contra a epidemia da aids, sendo também um espaço de pesquisa e intervenção, envolvendo agentes do movimento homossexual (espaço militante), do campo médico, que também eram docentes e pesquisadores (campo científico) ou atuavam na secretaria de saúde do estado (campo burocrático).

\section{Quem se interessava pela aids e por quê?}

Entre os 33 entrevistados, 20 inseriram-se no espaço aids até 1986. Oito no subespaço burocrático, seis no subespaço militante e seis no subespaço científico. O interesse desses agentes pela aids, ou seja, aquilo que os motivou a entrar nesse espaço de lutas e intervenção médico-sanitária de resposta à epidemia, no período entre 1983 e 1986 esteve relacionado ou ao pertencimento a grupos de risco ou ao contato prévio com a doença, seja por motivos pessoais; doentes, parentes e amigos, ou amigos de profissionais ou militantes que também se sensibilizavam com a epidemia, seja por questões profissionais, associadas ou não a razões de ordem pessoal. (Quadro 3) 
QUADRO 3 - Perfil dos entrevistados, segundo graduação, ano de entrada no espaço aids, subespaço de inserção, volume de capital científico, burocrático, político e militante, relação com a aids e presença no espaço aids na emergência da política nacional de controle da epidemia (1985)

\begin{tabular}{|c|c|c|c|c|c|c|c|c|c|c|}
\hline \multirow[b]{2}{*}{$E$} & \multirow[b]{2}{*}{$\begin{array}{l}\text { Graduação } \\
\text { (instituição, ano) }\end{array}$} & \multirow{2}{*}{ 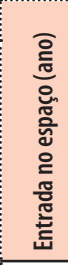 } & \multirow[b]{2}{*}{ 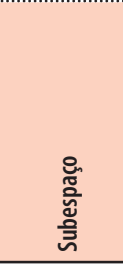 } & \multicolumn{5}{|c|}{ Volume de capital (1983-1986) } & \multirow[b]{2}{*}{$\begin{array}{l}\text { Relação com } \\
\text { a aids }\end{array}$} & \multirow{2}{*}{ 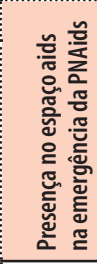 } \\
\hline & & & & $\frac{\text { 旁 }}{3}$ & : & 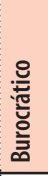 & $\frac{.3}{\frac{3}{2}}$ & 壱 & & \\
\hline 1 & Ciências Sociais (PUC-SP, 1992) & 1983 & Burocrático & $E M$ & - & - & - & - & Profissional & $x$ \\
\hline 2 & Medicina (UFBA, 1985) & 1993 & - & & & & & & Profissional & \\
\hline 3 & Direito (PUC-SP, S/I) & 1983 & Militante & $S$ & - & - & $P$ & $P$ & $\begin{array}{l}\text { Profissional/ } \\
\text { Pessoal }\end{array}$ & $x$ \\
\hline 4 & Medicina (UFBA, 1969) & 1983 & Científico & $P G$ & $A A$ & $P$ & $p$ & - & Profissional & $x$ \\
\hline 5 & Ciências Sociais (UFRJ, 1988) & 1989 & Militante & & & & & & Profissional & \\
\hline 6 & Filosofia (UNESP, S/I) & 1994 & Militante & & & & & & Pessoal & \\
\hline 7 & Medicina (UFRJ, 197?) & 1983 & Científico & $S$ & - & - & - & - & Profissional & \\
\hline 8 & $\begin{array}{l}\text { Psicologia Social (Univ. Sussex } \\
1968 \text { ) }\end{array}$ & 1983 & Militante & $P G$ & $M$ & - & - & $P$ & Política & $x$ \\
\hline 9 & Medicina (UFBA, 1965) & 1985 & Científico & $P G$ & $A$ & - & - & - & Pesquisa & $x$ \\
\hline 10 & Medicina (UFBA, 1968) & 1985 & Burocrático & $P G$ & $P$ & $A A$ & $p$ & - & Profissional & $x$ \\
\hline 11 & Medicina (UFPI, 1983) & 1986 & Burocrático & $S$ & - & $A$ & - & - & $\begin{array}{l}\text { Profissional/ } \\
\text { Pessoal }\end{array}$ & $x$ \\
\hline 12 & $\begin{array}{l}\text { Administração (Centro } \\
\text { Universitário Metodista - SP, } \\
\text { após 2001) }\end{array}$ & 1986 & Militante & & & & & & Pessoal & \\
\hline 13 & $\begin{array}{l}\text { Hotelaria (Faculdade Hebraico } \\
\text { Brasileira Renascença, 1994) }\end{array}$ & 1994 & Militante & & & & & & Pessoal & \\
\hline 14 & $\begin{array}{l}\text { Administração (UCSAL, após } \\
\text { 2001) }\end{array}$ & 1987 & Militante & & & & & & & \\
\hline 15 & Turismo $(S / I)$ & 1986 & Burocrático & $S$ & - & $P$ & - & - & Profissional & \\
\hline 16 & Medicina (EBMSP, 1981) & 1990 & Científico & & & & & & Profissional & \\
\hline 17 & $\begin{array}{l}\text { Sociologia (Escola de Sociologia } \\
\text { Política de São Paulo, S/I) }\end{array}$ & 1992 & Burocrático & & & & & & Profissional & \\
\hline 18 & $\begin{array}{l}\text { Matemática (Universidad de } \\
\text { Buenos Aires, 1972) }\end{array}$ & 1986 & Militante & $P G$ & $M$ & - & $P$ & $A$ & Pessoal & \\
\hline 19 & Medicina (USP, 1961) & 1983 & Científico & $P G$ & $A$ & $A$ & $P$ & - & Profissional & $x$ \\
\hline 20 & Ciências Sociais (USP, 1968) & 1983 & Militante & $P G$ & $M$ & - & $P$ & $A$ & Política & $x$ \\
\hline 21 & Economia (UnB, após 2001) & 1986 & Burocrático & $E F$ & - & - & - & - & Profissional & \\
\hline 22 & Psicologia (UFBA, 1991) & 1987 & Militante & & & & & & Pessoal & \\
\hline 23 & Medicina (UFBA, 1989) & 1990 & Burocrático & & & & & & & \\
\hline 24 & Medicina (EMESCAM, 1975)* & 1985 & Burocrático & $S$ & - & $A$ & - & $P$ & Profissional & $x$ \\
\hline 25 & Ciências Sociais (Unesp, 1987) & 1988 & Científico & & & & & & & \\
\hline 26 & Medicina (Unesp, 1973) & 1983 & Burocrático & $S$ & - & $A$ & - & $P$ & Profissional & $x$ \\
\hline 27 & Medicina (UFRJ, 1986) & 1986 & Burocrático & $S$ & - & $A$ & - & - & Profissional & \\
\hline
\end{tabular}




\begin{tabular}{|c|c|c|c|c|c|c|c|c|c|c|}
\hline \multirow{2}{*}{$\mathrm{E}$} & \multirow{2}{*}{$\begin{array}{l}\text { Graduação } \\
\text { (instituição, ano) }\end{array}$} & \multirow{2}{*}{ 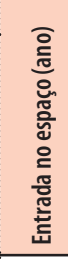 } & \multirow[b]{2}{*}{ 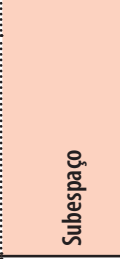 } & \multicolumn{5}{|c|}{ Volume de capital (1983-1986) } & \multirow{2}{*}{$\begin{array}{l}\text { Relação com } \\
\text { a aids }\end{array}$} & \multirow{2}{*}{ 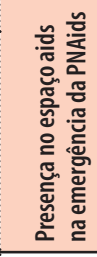 } \\
\hline & & & & $\frac{\overline{0}}{3}$ & 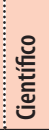 & 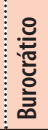 & $\frac{\stackrel{2}{*}}{\frac{3}{2}}$ & 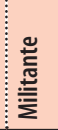 & & \\
\hline 28 & $\begin{array}{l}\text { Tecnólogo em processamento } \\
\text { de dados (S/I) }\end{array}$ & 1993 & Burocrático & & & & & & Profissional & \\
\hline 29 & Psicologia (PUC, 1978) & 1986 & Militante & $P G$ & $P$ & - & $p$ & A & Profissional & \\
\hline 30 & Medicina (UERJ, 1985) & 1986 & Científico & $S$ & - & - & - & - & Profissional & \\
\hline 31 & Medicina (Unifesp, 1973) & 1983 & Científico & $\begin{array}{l}\text { PG } \\
\text { P }\end{array}$ & $M$ & $\vdots-$ & - & $\vdots-$ & Profissional & $x$ \\
\hline 32 & Psicologia (USP, 1977) & 1984 & Científico & & & & & & Profissional & $x$ \\
\hline 33 & Psicologia (UERJ, 1985) & 1985 & Militante & $P G$ & $P$ & - & $p$ & A & Política & $x$ \\
\hline
\end{tabular}

Fonte: Elaborado pela autora.

Notas: E: entrevistado; PUC-SP: Pontifícia Universidade Católica de São Paulo; UFBA: Universidade Federal da Bahia; S/I: sem informação; UFRJ: Universidade Federal do Rio de Janeiro; Unesp: Universidade Estadual Paulista "Júlio de Mesquita Filho"; US: University of Sussex; UFPI: Universidade Federal do Piauí; UCSal: Universidade Católica de Salvador; EBMSP: Escola Bahiana de Medicina e Saúde Pública; UBA: Universidad de Buenos Aires; USP: Universidade de São Paulo; UnB: Universidade de Brasília; EMESCAM: Escola Superior de Ciências da Santa Casa de Misericórdia de Vitória; PUC-RJ: Pontifícia Universidade Católica do Rio de Janeiro; UERJ: Universidade do Estado do Rio de Janeiro; Unifesp: Universidade Federal de São Paulo; EM: ensino médio; S: superior completo; PG: pós-graduação; EF: ensino fundamental, AA: volume de capital científico muito alto; M: volume de capital científico médio; A: volume de capital científico alto; B: volume de capital científico baixo; PNAids: Política Nacional de Aids

*Contato por correspondência eletrônica.

Aqueles que entraram no espaço, exclusivamente a partir de um motivo pessoal, eram todos participantes de movimentos homossexuais ou já tinham diagnóstico sorológico para HIV. A sua inserção no espaço aids se deu a partir do subespaço militante. Alguns continuaram no espaço aids, como E20 e E18, sendo que o primeiro mantendo-se no movimento gay e o segundo em associações específicas de luta contra a aids. Outros migraram para os demais subespaços, como E8, que transitou pelo espaço burocrático e consolidou-se no espaço científico, desvinculando-se em meados da década de 1990 do espaço aids. Lutar contra a aids era lutar em defesa da causa homossexual, não apenas como uma questão de sobrevivência, mas também relacionada à concepção da doença, da sexualidade, de suas práticas.

Os agentes que começaram a sua relação com a aids, devido a questões profissionais, inseriram-se principalmente no campo científico ou 
burocrático, assumindo posições em programas estaduais e no Programa Nacional (E26, E27, E1). Duas agentes incorporaram-se ao espaço militante: E3, no Grupo de Apoio e Prevenção à Aids (Gapa), e E29, na Associação Brasileira Interdisciplinar de Aids (Abia). É importante notar que são duas situações bastante específicas. E3 participou de uma das reuniões iniciais de formação do Gapa devido a um encontro profissional com uma cliente que era assistente social do Hospital Emílio Ribas. Mas no seu relato também citou a participação de pelo menos um amigo naquela reunião.

[...] eu não tinha nenhuma vinculação, até porque, não suportava e mesmo assim hoje eu tenho um pavor de doença, [...] Eu tinha uma cliente que era assistente social, $[. .$.$] e ela [. .$.$] falou que precisava ter uma conversa comigo enquanto ad-$ vogada. Eu falei: 'Tudo bem, pode vir aqui hoje.' [...] Aí ela: 'Não, vai ser muito tarde, daria para você me encontrar lá??' [...] Eu fiquei pensando, para eu sair do escritório, ir para minha casa... Eu decidi ir direto [...], tinha uma reunião. Aí eu comecei a participar. [...] estava todo mundo sentado em círculo e eu sentei na cadeira depois, no outro círculo. Porque eu não fazia parte daquela reunião [...] sobre aids. Uma das primeiras reuniões... O que vai fazer, o que não vai fazer... E o pessoal todo desesperado. E eu, [...] verificando assim pela parte mais prática, sem a emoção da situação, eu via a solução. Eu ficava pensando: por que eles não fazem tal coisa? [...] E eu peguei a pessoa falando e eu já mentalizando como éque seria. Quando terminou a reunião, começou a passar uma relação em uma lista para saber quem estava presente na reunião e quem podia ajudar, qual horário, aquela coisa toda. Aí veio passando e quando chegou na mão de um amigo nosso que era voluntário e estava naquele momento ali, [...] passou para mim. Aí eu falei: 'Desculpa, mas eu estou fora da rodinha.' Ele falou: 'E você não pode ajudar porque esta fora da rodinha?' [...] eu olhei e vi que o único horário que eu tinha livre era sábado 3 horas da tarde, porque o resto da semana toda era ocupada. [...] depois eu verifiquei que a maioria também era no sábado. E coincidia o horário. Então nós começamos a fazer as reuniões a partir daquele ano, sábado às 3 horas da tarde. $\left(\mathrm{E}_{3}\right)^{33}$ Paulo, em 20 de junho de 2011. 
E3 associou a prática profissional à militância. Ela conseguiu construir uma trajetória militante relacionada à sua trajetória profissional, criando a primeira assistência jurídica para pessoas com HIV/aids. Em 2012 continuava atuando como advogada e militante.

E29 foi convidada por Betinho para elaborar o projeto da Abia na expectativa de, conseguindo um financiamento, tornar-se funcionária da instituição. Integrou-se ao quadro de funcionários da associação, assumindo uma posição intermediária na diretoria da Abia, de modo que fez uma trajetória profissional ao interior do subespaço militante. Saiu da Abia em 1991 e também da militância na área de aids.

[...] Começa com a proposta do Betinho para que eu viesse a ajudar a colocar em pé uma entidade, a Abia, que na época não tinha o nome de Abia. A ideia era fundar uma fundação que era um branch, uma sucursal da [International] Interdisciplinary Aids Foundation, IIAF, a ideia que ele tinha era que fosse uma fundação. Como a legislação de fundação no Brasil era muito problemática, resolvemos criar uma associação. A Abia não existia ainda, então o Betinho me convidou para isso. (E29) ${ }^{34}$

É interessante notar que os agentes com menor volume de capital cultural, ou escolar, e científico foram aqueles relacionados ao campo burocrático. Praticamente todos os agentes que possuíam algum volume de capital científico se inseriram no campo científico ou no espaço associativo. Dos seis agentes do espaço científico aqui analisados, apenas um não possuía pós-graduação stricto senso, todos os demais possuindo mestrado e/ou doutorado, que correspondiam respectivamente ao baixo e médio volume de capital científico. Contudo, os que apresentaram maior volume de capital científico foram aqueles que se mantiveram no subespaço científico, também ao interior do espaço aids, como E4, E9 e E19, sendo que este último teve uma participação inicial mais tangencial, enquanto diretor no Instituto de Saúde da SES-SP, depois dando seguimento a sua trajetória acadêmica voltado para o estudo de vacinas. 
Os agentes do subespaço burocrático foram os únicos a apresentar o capital especifico desse campo, à exceção, naquele momento, dos então estagiários do Programa Estadual de Aids de São Paulo, E1, e do Programa Nacional de Aids, E21, que fizeram carreira naquele subespaço até o final do período estudado, ou seja, os agentes do campo burocrático que foram trabalhar na área de aids eram técnicos de carreira, que já vinham assumindo posições na burocracia estatal ou recém-ingressos nesse campo.

Outra questão importante foi que nos espaços mais institucionalizados, como os campos burocrático e científico, havia um predomínio do campo médico. No campo burocrático, os médicos assumiram as posições dominantes (coordenadores, técnicos, assessores), enquanto os não médicos permaneceram nas posições menos qualificadas ao interior do aparelho estatal (técnico-administrativos).

Alguns dos agentes que tiveram importante participação na gênese e nas transformações do espaço aids tiveram uma trajetória política dominante. Não apenas através da filiação a partidos políticos, mas chegando a cargos eletivos, como o médico pediatra e ministro Carlos Sant'Anna e o médico sanitarista Sérgio Arouca, que foram eleitos deputados federais, ou aqueles que como Herbert Daniel, da Abia, concorreram, sem sucesso, a cargos eletivos.

Outros tiveram participação no movimento sanitário como E9, E10, E26, E27 e Paulo Bonfim, do Gapa; no movimento homossexual, a exemplo de E18, E8, E20, E33 e E26; na luta contra ditadura, participando de movimentos como a Ação Popular (AP) ${ }^{35}$ ou de partidos clandestinos como o Partido Comunista Brasileiro (PCB). ${ }^{36}$ Além disso, houve participações mais periféricas - não dominantes - na Convergência Socialista e, em especial, na fundação do Partido dos Trabalhadores (PT). A maioria dos agentes que possuía algum volume da capital político teve papel de destaque no espaço militante, assumindo posições dominantes, como a direção das ONGs/Aids ou outras organizações associativas.

E4 e E12 militaram no PCB. 
Contudo, o objeto em questão era a luta contra aids. A discussão era de políticas públicas que pudessem intervir na epidemia, não se tratando de política partidária. $\mathrm{O}$ apoio poderia vir de diferentes correntes políticas que abraçassem a causa e apoiassem as propostas da organização. Isso também não significava que os sujeitos não pudessem ser filiados a partidos políticos, contudo, evitava-se uma vinculação da instituição àquelas da política tradicional, bem como um posicionamento da instituição ou de seus membros na política partidária.

[...] uma vez que eu estava fazendo um curso para magistratura, e o professor chamava 'esses aidéticos baderneiros, não sei o que, esse movimento petista' e eu ficava pensando, mas meu Deus do céu, já não se fala mais assim há tanto tempo [...] um dia eu fuifalar com ele, aí ele falou: 'Não, para mim éassim, vocês estão dentro disso ai', que ele ainda foi bem agressivo, e era desembargador. 'Para vocês que são petistas...' Eu falei: 'Mas eu não sou petista'. Aíele falou: 'mas não, só pode ser petista para fazer essa baderna'. O trabalho que a gente considerava sério para eles era baderna. E também aqui dentro [da associação] nunca se tratou de política. Então podia vir como veio, o Ítalo, como veio a Rita de Cardoso, como veio outros, a Luisa Erundina, antes dela ser prefeita e antes dela ser deputada. Agente tinha os encontros. Mas você não tratava de política partidária e sim de política de saúde. Então, na cabeça da gente, isso estava muito claro. Nem bandeirola no carro, nem nada [...]. (E3)

Da mesma forma, o sociólogo Herbert de Souza, fundador da Abia, ainda que com uma trajetória militante importante, desde a adolescência tendo participado do movimento da Juventude Católica, do movimento estudantil, da fundação da Ação Popular (AP), do movimento operário e tendo sido exilado político, recusava-se a integrar a política partidária institucionalizada. Sua atuação era voltada para associações como Instituto Brasileiro de Análises Sociais e Econômicas (Ibase) e Abia.

Foram identificadas cinco concepções sobre a aids (Quadro 4):

1. A aids foi considerada como "uma doença", uma infecção, ou uma epidemia, o que correspondia a uma definição mais técnica, principalmente pelos agentes do campo burocrático; 
QUADRO 4-Concepções sobre a aids segundo agentes estudados, de acordo com subespaço de pertencimento, ano de entrada no espaço aids, sexo e formação

\begin{tabular}{|c|c|c|c|}
\hline Concepção sobre aids & Agente & Subespaço & Evidências nas entrevistas ou documentos \\
\hline \multirow[t]{7}{*}{ Doença/ Epidemia } & E1 & Burocrático & "É uma doença [...] era uma epidemia." \\
\hline & E10 & Burocrático & "É uma infecção pelo vírus HIV." \\
\hline & E11 & Burocrático & $\begin{array}{l}\text { "É uma doença, acho que é uma doença importante do ponto de vista biológico, } \\
\text { médico. [...] acho que é a doença do nosso século, tal como era a tuberculose no } \\
\text { passado." }\end{array}$ \\
\hline & E9 & Científico & "É uma doença que veio pra ficar. [...] É mais uma doença, só que tem estrela." \\
\hline & E15 & Burocrático & "É uma epidemia que começou tão pequena e que hoje está em todos os lugares." \\
\hline & E31 & Científico & $\begin{array}{l}\text { "Hoje, é uma doença como as outras [...], mas é um tratamento que ainda tem que } \\
\text { ser aperfeiçoado [...]." }\end{array}$ \\
\hline & E21 & Burocrático & $\begin{array}{l}\text { "É uma doença adquirida [...] As pessoas que não são contaminadas por acidente, } \\
\text { tipo transfusões de sangue, elas vão atrás, ou seja, relações de risco. Para mim a } \\
\text { aids fez o que eu sou hoje profissionalmente." }\end{array}$ \\
\hline \multirow{7}{*}{$\begin{array}{l}\text { Doença relacionada } \\
\text { a morte, ao perigo, } \\
\text { a reações de pânico, } \\
\text { pavor e medo, estigma } \\
\text { e discriminação }\end{array}$} & E3 & Militante & "No primeiro ano, se eu não perdi 30 amigos, eu perdi pouco." \\
\hline & E29 & Militante & "Uma epidemia causada por um vírus, que causava uma doença devastadora." \\
\hline & E18* & Militante & $\begin{array}{l}\text { "[...] a aids tem várias dimensões. [...] eu acho que na atualidade ocupa menos } \\
\text { espaço [...] porque entrou em uma estabilidade [...] Agora, continua carregado de } \\
\text { muito estigma, discriminação [...]" }\end{array}$ \\
\hline & $E 33^{*}$ & Militante & "E ela é preconceito, é discriminação ainda. [...] Mas também uma oportunidade." \\
\hline & E7 & Científico & $\begin{array}{l}\text { "Era uma coisa muito grande, perigosa, um risco enorme para a humanidade [...] } \\
\text { Hoje é o exemplo da capacidade do ser humano de se superar." }\end{array}$ \\
\hline & E31 & Científico & $\begin{array}{l}\text { "[...] Ela foi horrível! Ela foi o pior pesadelo, um pesadelo que não terminava. E que } \\
\text { só deixou de ser pesadelo quando a gente percebeu que se passaram } 20 \text { anos e as } \\
\text { pessoas que a gente atendeu há muito tempo não morreram. [...]." }\end{array}$ \\
\hline & E4 & Científico & $\begin{array}{l}\text { "Foi um mal muito grande, mas no bojo desse mal muitas coisas aconteceram. } \\
\text { [...] a aids trouxe coisas horrorosas, terríveis devastadoras, mas ao mesmo tempo } \\
\text { forçou a sociedade a se organizar para combatê-la." }\end{array}$ \\
\hline \multirow{4}{*}{$\begin{array}{l}\text { Problema social ou de } \\
\text { saúde pública }\end{array}$} & E15 & Burocrático & "[...] ainda é um desafio para a saúde pública." \\
\hline & E18* & Militante & $\begin{array}{l}\text { "[...] a aids tem várias dimensões. [...] eu acho que na atualidade ocupa menos } \\
\text { espaço [...] porque entrou em uma estabilidade [...]" }\end{array}$ \\
\hline & E33* & Militante & $\begin{array}{l}\text { "É uma doença, mas é uma crise porque ela envolve tantas questões morais, } \\
\text { políticas, sociais, culturais, que entram em xeque com a epidemia." }\end{array}$ \\
\hline & $E 8^{*}$ & $\begin{array}{l}\text { Militante/ } \\
\text { Científico }\end{array}$ & $\begin{array}{l}\text { "Era uma coisa muito forte, muito grande, é uma doença que tem um monte de } \\
\text { conotações políticas, culturais, virou do ponto de visto das pessoas uma doença } \\
\text { crônica, mas eu acho que é mais sério do que isso." }\end{array}$ \\
\hline \multirow[t]{4}{*}{ Problema de pesquisa } & $\begin{array}{l}\text { Herbert } \\
\text { de Souza }\end{array}$ & Militante & $\begin{array}{l}\text { "É uma doença que desafia e que diz para a ciência o seguinte: ou você me decifra } \\
\text { ou eu te engulo." (SOUZA, H. Memória Roda Viva: Debate aids. 19/01/1987: 1-57 } \\
\text { p. 1987) }\end{array}$ \\
\hline & $E 4$ & Científico & "[...] forçou a sociedade a se organizar para combatê-la." \\
\hline & E30 & Científico & $\begin{array}{l}\text { "Hoje, é uma doença como as outras [...], mas é um tratamento que ainda tem que } \\
\text { ser aperfeiçoado[..." }\end{array}$ \\
\hline & E7 & Científico & $\begin{array}{l}\text { "Era uma coisa muito grande, perigosa, um risco enorme para a humanidade [...] } \\
\text { Hoje é o exemplo da capacidade do ser humano de se superar." }\end{array}$ \\
\hline $\begin{array}{l}\text { Ameaça à liberação } \\
\text { sexual }\end{array}$ & $E 20^{*}$ & Militante & "[...] a aids foi um balde de agua fria na fervura da liberação sexual dos anos $80 . "$ \\
\hline
\end{tabular}

Fonte: Elaborado pela autora.

Nota: *Participantes do movimento homossexual. 
2. Alguns agentes dos três subespaços também a definiram como "um problema social ou de saúde pública”, mantendo o caráter técnico trazido na concepção dos agentes do campo burocrático, mas acrescentando um caráter social e a responsabilização do Estado e/ ou da sociedade;

3. Agentes do espaço militante e do campo científico, envolvidos desde os primeiros momentos na luta contra a epidemia, a definiram como "uma doença relacionada à morte, ao perigo, a reações de pânico, pavor e medo, estigma e discriminação". Essa visão pode ser evidenciada também em diversos trechos das entrevistas apresentados ao longo deste livro;

4. Para os agentes do campo científico, a aids era "um problema de investigação", relacionado ao desconhecimento então existente naquele período acerca da doença. Essa concepção também era partilhada pelo sociólogo Herbert de Souza, fundador da Abia;

5. Outra concepção identificada foi a de "uma ameaça à liberação sexual”, manifestada por um militante do movimento homossexual.

Apesar de não comungarem da mesma visão sobre o que é a aids e, consequentemente, das medidas a serem adotadas para o seu enfrentamento, essa diversidade de concepções contribuiu para uma complementaridade, de modo que o problema foi construído de forma ampla e as ações baseadas na dignidade dos doentes e nos direitos humanos. Nesse sentido, a Comissão Nacional de Aids, como instância estatal, na qual os poderes científico e militante estavam concentrados e transmutados em poder burocrático de normalização, teve importante papel na construção de um discurso oficial que contemplasse a negociação entre os agentes dos diferentes subespaços.

A partir da criação desse novo espaço de lutas, dos enfrentamentos entre os agentes desses diferentes subespaços com a chegada do processo de redemocratização ao governo federal e eleições para presidente da república marcadas para janeiro de 1985, bem como a ocorrência de casos de aids para além do eixo Rio-São Paulo, que começaram a surgir as 
primeiras medidas mais específicas para o controle da epidemia e a implantação de uma política nacional de luta contra a aids no país.

\section{A resposta do Ministério da Saúde}

Nos primeiros anos da epidemia, o governo federal quase não se pronunciava, mas também não era questionado pela imprensa e pela comunidade científica. Durante o $20^{\circ}$ Congresso da Sociedade Brasileira de Medicina Tropical, realizado em 1984, em Salvador, a aids ainda não era vista como um problema a ser priorizado pelo Ministério da Saúde.

Em 1984, a comunidade acadêmica já sabia sobre a expansão da doença nos EUA, mas não entendia que era ainda um problema brasileiro. Me lembro de ter ido a um congresso de DST em Salvador com Paulo Teixeira, de São Paulo, e planejamos uma intervenção plenária para falar do problema e a possibilidade de se tirar uma carta ao Ministério da Saúde. Quase fomos vaiados. Na verdade apenas as SES de São Paulo, Rio Grande do Sul e Rio de Janeiro começavam a se organizar tendo como modelo São Paulo. (E24) ${ }^{37}$

A Folha de São Paulo, no período de 1983 e 1984, não divulgou notícias relacionando o Ministério da Saúde e a epidemia da aids. As notícias veiculadas sobre a epidemia concentravam-se na ocorrência de casos em São Paulo, estado com maior número de pessoas acometidas pela aids no país, e eventualmente nos demais estados; nas ações do Programa de Aids da SES-SP; e em notícias vindas do exterior. ${ }^{38}$ Há o registro de que, em junho de 1983, o Ministério da Saúde elaborou um documento denominado "Aids - informações básicas" que reunia o resumo de alguns artigos publicados no exterior, falava da epidemia nos EUA, mas não fazia referência aos casos brasileiros, que já estavam sendo divulgados pela imprensa médica e também pela imprensa leiga. (TEIXEIRA, 1997)

Mensagem pessoal enviada porE24, médica egestora. Mensagem recebida por <sgb@ufba.br> em 12 abr. 2012.

38 Consulta ao acervo on line da Folha de São Paulo, disponível em <http://acervo.folha.com. br/>, para o período entre 01/01/1983 e 15/03/1985. 
O Departamento de Dermatologia Sanitária do Ministério da Saúde, 1983, 1984, principalmente, tinha uma posição muito reticente, até de oposição. Considerando que não era um agravo de saúde pública que explicasse as ações que estavam sendo feitas, e com as Dermatologias se envolvendo, isso trazia para o âmbito do Ministério uma determinada agitação em relação ao tema. [...] foi uma posição decrítica. (E26)

A situação no Ministério da Saúde começou a mudar em 1985. “Até então, seus representantes se pautaram por minimizar a dimensão do problema e criticar as ações programáticas adotadas pelas diversas unidades federadas". (TEIXEIRA, 1997, p. 55)

No final do período da ditadura militar, após a realização de eleições indiretas para presidente da república emjaneiro 1985 e da eleição de Tancredo Neves, do PMDB, as ações relacionadas ao controle da epidemia da aids, no governo federal, iniciaram-se no âmbito do Programa Capacitação de Recursos Humanos para o Controle de Infecções Hospitalares, ${ }^{39}$ coordenado pelo Dr. Luiz Carlos Pelizari Romero, da Secretaria Nacional de Programas Especiais de Saúde (SNPES). Embora o programa houvesse iniciado no final de 1983, a primeira reunião relacionada à aids aconteceu em fevereiro de 1985, ainda nos últimos meses do governo Figueiredo. O Ministro da Saúde era Waldyr Mendes Arcoverde ${ }^{40}$ e Fabíola de Aguiar Nunes, médica baiana, sanitarista, com trajetória profissional em diferentes níveis da burocracia estatal da saúde, ocupava, naquele momento, um cargo no Ministério da Educação e Cultura (MEC) e também participava do programa como sua representante..$^{41}$

O Projeto Capacitação de Recursos Humanos para Controle da Infecção Hospitalar foi instalado em fins de 1983 pelo Ministério da Saúde. Seu primeiro encontro de avaliação aconteceu entre os dias 16 e 19 de dezembro de 1985. (INFECÇÃO..., 1985)

Médico sanitarista, foi Ministro da Saúde no período de 30/01/1979a 14/03/1985, pretendia interiorizar as ações básicas de saúde nas regiões mais pobres, na sua gestão tiveram início as pesquisas na Fiocruz para o desenvolvimento de uma vacina contra o sarampo.

41 "[... ] na troca do governo, eu tinha participado enquanto MEC da elaboração do programa nacional de controle de infecção hospitalar que o ministério da saúde fez e não usou. [...] analisar o problema de infecção hospitalar é complicado e ninguém sabia nada, só que estava matando, não adiantava a vigilância sanitária, tinha que começar com um treinamento. O que é que o ministério fez? Ainda estava nas AIS, era uma ação interministerial e eu entrei pelo 
Tancredo Neves não chegou a assumir a presidência, mas o vice-presidente, José Sarney, manteve inicialmente os ministros por ele escolhidos. Carlos Sant'Anna, médico pediatra, deputado baiano pelo PMDB eleito em 1982, antes eleito pela Aliança Renovadora Nacional (ARENA) em 1978, e um dos articuladores da campanha de Tancredo, assumiu o Ministério da Saúde, tomando posse em 15 de março de 1985.

Quando Carlos Sant'Anna assumiu o Ministério, Fabíola de Aguiar Nunes foi convidada a assumir a Secretaria Nacional de Programas Especiais de Saúde (SNPES), no Ministério da Saúde, no qual, no âmbito da Divisão Nacional de Dermatologia Sanitária (DNDS), seria criado o Programa Nacional de DST/Aids. A indicação de Fabíola Nunes, ainda que essa fosse companheira de Carlos Sant'Anna, veio do Secretário de Estado de Saúde de São Paulo, João Yunes. (E1O) ${ }^{42}$ O responsável pela DNDS era o médico dermatologista Aguinaldo Gonçalves, ${ }^{43}$ que foi mantido inicialmente no cargo. No início, a nomeação da esposa do ministro para a secretaria foi criticada na imprensa. (A MULTIPLICAÇÃO..., 1985) As primeiras ações realizadas pelo Ministério da Saúde, em 1985, estavam relacionadas à definição de casos e, principalmente, com a criação

MEC. Se fez uma proposta nacional de treinamento de profissionais de saúde de hospitais, começando com os de grande porte. [...] Eu participei desse negócio todo nos bastidores, caladinha láno MEC. [...] Quando chegou no mês de janeiro, que Tancredo tinha ganho, a posse ia ser em março. Não sei se você se lembra disso. Foram três meses, Tancredo eleito e os militares, aí, foi uma orgia de jogar dinheiro fora, para a nova república chegar sem dinheiro. No MEC também. Eu chamei Dr. Romero, que hoje está no senado, e naquela época estava no ministério da saúde [...] Conseguimos todo o dinheiro, entre janeiro e março a gente treinou 12 hospitais no centro de treinamento, criou todos os manuais." (E10, entrevista concedida à profa. Ligia Maria Vieira da Silva, em 12/11/2008, Projeto Espaço da Saúde Coletiva)

Entrevista concedida por E10, em Salvador, em 14 de julho de 2011.

Aguinaldo Gonçalves nasceu em 18 de agosto de 1949, em Santos, São Paulo. Médico formado pela Unesp (em 1967), especialista em Medicina de Trabalho (1974), Saúde Pública (1976) pela USP. mestre (1977) e doutor (1980) em Ciências Biológicas (Biologia Genética), também na USP (1977). Professor de Epidemiologia, Dermatologia Sanitária e Controle da Hanseníase da Faculdade de Saúde Pública da USP entre 1977-1980. Foi convidado pelo ministro da Saúde, Waldyr Arcoverde, para trabalhar como diretor da Divisão Nacional de Dermatologia Sanitária, a partir de 1980. Ao deixar essa função, entre 1986 e 1988, atuou como analista de desenvolvimento científico no CNPq. Recebeu a medalha de mérito "Vacuna contra la Lepra"(1983), concedida pela Asociación para la Investigación Dermatológica, em Caracas, Venezuela. Em 1988 tornou-se professor titular em Saúde Coletiva da Faculdade de Educação Física, da Universidade de Campinas (Unicamp), São Paulo. (MACIEL; OLIVEIRA; GALLO, 2010, p. 34-36) 
de um sistema de vigilância epidemiológica para a aids. Participaram das primeiras reuniões o coordenador do Programa Estadual de DST/Aids de São Paulo, Paulo Roberto Teixeira, o médico Vicente Amato Neto, ${ }^{44}$ professor de infectologia da USP, e técnicos de outros estados. (E1O; E11; E24) A $1^{\text {a }}$ reunião foi realizada no dia 14 de fevereiro de 1985 , no último mês do governo militar, no Ministério da Saúde, com a comunidade científica. Teve como objetivo revisar a literatura especializada sobre aids e como resultado a minuta da portaria para controle da infecção hospitalar em pacientes com aids.

Àquela altura já havia uma reivindicação dos movimentos sociais, não apenas de homossexuais, mas também de talassêmicos e hemofílicos, cobrando uma resposta do governo; a imprensa falava insistentemente do assunto (E10; E26) e, além de São Paulo, os estados do Rio de Janeiro e Rio Grande do Sul já tinham estruturado algumas ações (E24), também pressionando o governo federal a tomar uma decisão. Some-se ainda a representação social da doença, associada ao pavor e ao medo.

A imprensa enfatizava a mortalidade, o grupo de risco (homossexuais) e o desconhecimento da doença, mas ainda não havia critério diagnóstico definido.

$\mathrm{Na}$ ocasião que eu estou falando, não se sabia nada. Era uma doença nova que tinha uns sintomas muito agudos, quer dizer, a pessoa adquiria aquela doença, começava a ter febre alta, emagrecimento excessivo, muita diarreia, uma indisposição terrível e geralmente quem tinha essa doença em 6 meses estava morto. Esse era o quadro. O próprio CDC [Centers for Disease Control and Prevention, EUA] em março de 1985, não tinha uma definição de caso clara, nem um critério de diagnóstico. O critério de diagnóstico era clínico. [...] Quando nós assumimos, tinham duzentos e setenta e dois casos, metade diagnosticado nos últimos dois anos, e a outra metade nos últimos dois meses. (E10) a partir de 1977. Diagnosticou o primeiro caso de aids autóctone brasileiro (1982). Presidiu durante vários anos a Comissão de Aids da Secretaria da Saúde do estado de São Paulo. Foi membro e secretário executivo da Comissão Nacional de Aids. 
Foram realizadas reuniões em São Paulo (13 a 15/03/ 1985) e Brasília (27 a 29/03/1985) com o objetivo de revisar e discutir os casos diagnosticados até aquele momento, tendo como produtos, respectivamente, a normalização de procedimentos no manejo da aids e a redação, por um grupo de especialistas nacionais, da minuta da portaria ministerial, ${ }^{45}$ que definiu critérios diagnósticos e estratégias de ação para o controle da epidemia de aids no país. (BRASIL, 1985b) Propunha-se a investigação epidemiológica, clínica, laboratorial e educação sanitária de casos suspeitos e confirmados, bem como de comunicantes e a realização de programa de educação sanitária para grupos em risco - homossexuais e bissexuais masculinos, usuários de drogas injetáveis, hemofílicos ou politransfundidos. A portaria mencionava o uso de preservativo, a utilização de seringas e agulhas descartáveis ou de uso individual e o controle da qualidade do sangue como medidas preventivas. (BRASIL, 1985b) Além disso, foi organizado um sistema para que todos os estados que ainda não tinham casos notificados, à medida que esses fossem sendo identificados, enviassem representantes para serem treinados em São Paulo. (E1O; E26) (BRASIL, 1985a)

Em meados de 1985, a Dermatologia Sanitária da Secretaria de Saúde do Estado do Rio de Janeiro (SES-RJ) também começou a organizar o seu programa estadual. Foi criada a Comissão Interinstitucional de Combate e Controle da Aids no estado do Rio de Janeiro. O governador era Leonel Brizola, fundador do Partido Democrático Trabalhista (PDT), eleito pelo voto direto em 1982, e o secretário de Saúde do Estado era Eduardo Azeredo Costa, médico com doutorado pela London School of Hygiene

A portaria n. 236, assinada no dia 2 de maio de 1985, criou o programa de controle da aids, delegando à DNDS a coordenação, determinando as medidas de prevenção a serem adotadas no país junto a comunicantes e casos confirmados (indivíduo que, pertencendo a algum grupo de risco, apresente uma ou mais das seguintes entidades mórbidas: 1- Sarcoma de Kaposi, em indivíduos com menos de sessenta anos de idade; 2-Linfoma limitado ao cérebro;3-Pneumonia por Pneumocystis; 4- Toxoplasmose, causando pneumonia ou infecção do sistema nervoso central; 5- Strongiloidiase, causando pneumonia, infecção do sistema nervoso central ou infecção generalizada; 6- Candidíase, causando esofagite; 7- Criptococose, causando infecção pulmonar, do sistema nervoso central ou disseminada; 8- Micobacterioses atípicas, comprovadas através de cultura; 9- Infecções causadas por citomegalovírus no pulmão, no trato gastrointestinal, sistema nervoso central, supra-renal e pâncreas; 10- Infecções por vírus herpes, tipo um ou dois, mucocutâneas (com úlceras que persistem por mais de um mês), pulmonares, do aparelho digestivo, ou disseminadas; 11- Leucoencefalopatia multifocal progressiva. 
\& Tropical Medicine. A médica dermatologista Maria Leide Wan del Rey de Oliveira ${ }^{46}$ coordenava o Programa Estadual de Dermatologia Sanitária desde 1983 e trabalhou na organização do Programa Estadual de Aids, com apoio do Hospital Universitário Clementino Fraga Filho (HUCFF), onde eram atendidos os casos suspeitos, e do laboratório da Fiocruz, que fazia o teste Elisa. Após um treinamento em Doenças Sexualmente Transmissíveis (DST) promovido pela OPAS, em Porto Rico, do qual ela participou junto com Paulo Roberto Teixeira, de São Paulo, Aguinaldo Gonçalves, da DNDS, e um médico de referência de Brasília, Maria Leide Wan del Rey de Oliveira elaborou o plano que levou à ampliação da equipe da Dermatologia Sanitária do Rio de Janeiro. Ampliação essa que permitiu a entrada do médico sanitarista Álvaro Matida no Programa Estadual de Aids, substituindo Cláudio Amaral na presidência da Comissão. Colaboraram com o Programa de Aids da SES-RJ os grupos homossexuais Triângulo Rosa e, a partir de 1986, o Atobá. (FATAL, 1988)

Ainda assim, o Ministro da Saúde, Carlos Sant'Anna, seguia afirmando: “trata-se de uma doença preocupante, mas não prioritária”, destacando a existência de outras doenças de maior prevalência como Chagas, hanseníase e esquistossomose (A MULTIPLICAÇÃO..., 1985, p. 56), visão que pode ter limitado a resposta inicial do governo federal, principalmente em relação aos recursos financeiros, ainda que a política nacional tenha sido implantada precocemente quando comparada à realidade de outros países.

No início de 1986, devido a divergências acerca da política de controle de hanseníase conduzida por Aguinaldo Gonçalves, Fabíola Nunes convidou Maria Leide Wan del Rey de Oliveira para assumir a Divisão Nacional de Dermatologia Sanitária (DNDS). (E10; E24)

Quando Maria Leide chegou à DNDS, em janeiro de 1986, existia uma técnica responsável pela aids, médica veterinária e sanitarista, mas não existiam condições de trabalho, nem orçamento. Maria Leide convidou inicialmente Miriam Franchini, que trabalhava com DST em Brasília, e

46 Maria Leide Wan del Rey de Oliveira, médica dermatologista, servidora do Inamps e professora da UFRJ, que participou do Movimento Popular de Saúde e fundou o $1^{\circ}$ núcleo do Movimento de Reintegração das Pessoas atingidas pela Hanseníase (Morhan) no Rio de Janeiro, era coordenadora do Programa Estadual de Dermatologia Sanitária do Rio de Janeiro. (OLIVEIRA, 2008) 
Lúcia Amaral, “uma sanitarista recém-saída da Fiocruz, que foi nosso braço direito na aids inicialmente e grande responsável pelo sistema de notificação inicial". (E24) Miriam Franchini ficou responsável pelas doenças sexualmente transmissíveis. (OLIVEIRA, 2008) Lair Guerra de Macedo Rodrigues, biomédica, professora da UnB, que havia feito especialização nos Centers for Disease Control and Prevention (CDC) nos EUA, e trabalhava no Programa de Saúde da Mulher foi convidada por Maria Leide para assumir a aids devido a uma palestra que havia assistido em $1984 \mathrm{du}-$ rante $\mathrm{o} 20^{\circ}$ Congresso da Sociedade de Medicina Tropical, no qual ela falava da experiência nos CDC; às boas referências sobre o seu trabalho; o fato de que ela estava saindo do Programa de Saúde da Mulher; e a possibilidade de influência e apoio internacional visto que a mesma era irmã de Carlyle Guerra de Macedo, representante da Organização Panamericana de Saúde (OPAS). Segundo Maria Leide, na mesma semana em que foi convidada, Lair Guerra entrou na sua sala dizendo: "Carlyle me disse que você colocou em minha mão uma missão de trabalho para o Brasil”. (E24)

Foi também com a entrada de Maria Leide na DNDS que teve início o comitê de grupos de risco e depois a Comissão Nacional de Aids, que serão detalhados mais adiante. Na minuta que deu origem à portaria $\mathrm{n}^{\circ}$ 236/1985, que oficialmente criou o programa nacional, existia um item denominado "Componentes do Programa de SIDA/AIDS", que propunha a criação de uma Comissão Interinstitucional nos estados, incluindo representantes da secretaria de saúde, Inamps, hospitais universitários, Pró-Sangue e outros serviços relacionados. A sua função seria coordenar as atividades de controle da aids, coletar dados, selecionar e avaliar o programa local, em consonância com as diretrizes nacionais. Esse item, contudo, não consta da portaria publicada no Diário Oficial da União.

Assim, para a decisão política e o desenvolvimento de uma política de controle da epidemia da aids contribuíram agentes que não estariam expostos ou não se importariam de se expor a interrogações acerca de uma eventual homossexualidade, como aconteceu com Michèle Barzach, na definição da política de aids na França. (PINELL et al., 2002) Ou seja, mulheres, como Fabíola Nunes e Lair Guerra, ou um ex-militante do movimento homossexual, como Paulo Roberto Teixeira. 
As articulações internacionais de Lair nos CDC e na OPAS, assim como sua capacidade de gestão ajudaram na estruturação inicial e ampliação do Programa de DST/Aids. Este também contou com uma colaboração importante da Fundação Serviços Especiais de Saúde Pública (FSESP) para a sua interiorização, ${ }^{47}$ através de seu representante para doenças transmissíveis, o médico sanitarista Pedro Chequer, que em seguida iria integrar também a equipe do Programa Nacional. (OLIVEIRA, 2008)

\section{A aids, a $8^{\text {a }}$ Conferência Nacional de Saúde e a Assembleia Nacional Constituinte}

Após entrar na agenda do Ministério da Saúde, a aids foi incluída em um

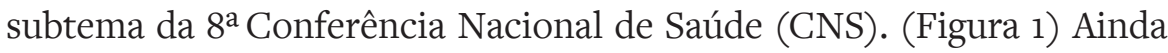
que o relatório específico não tenha sido localizado, como desdobramento das discussões na $8^{\text {a }} \mathrm{CNS}$ foram realizados debates em diversos estados, sob a coordenação do Ministério da Saúde, para se discutir o tema "Aids e Constituinte", sendo o primeiro realizado em Belo Horizonte, ainda em agosto de 1986. (BRASIL, 1986b; MÉDICO..., 1986; TEIXEIRA et al., 1987) Os debates tinham o objetivo de discutir como o novo sistema de saúde poderia resolver o problema da aids. Essas discussões inclusive pautaram a campanha nacional lançada em 1987. (TEIXEIRA et al., 1987)

Além de constar no subtema "Vigilância Epidemiológica (grandes endemias, doenças evitáveis por imunização e AIDS)", a aids também estava relacionada à mobilização do subtema "Sangue e Hemoderivados". Foi a contaminação pelo HIV através de transfusão sanguínea de talassêmicos, renais crônicos e, em especial, hemofílicos que reforçou a necessidade de controle da qualidade do sangue no país. Na década de 1980, não havia qualquer controle sobre o comércio de sangue e hemoderivados, sendo estes importantes veículos de transmissão de doenças. Diversas pessoas submetidas à transfusão foram contaminadas e morreram, sendo um dos mais famosos, o cartunista Henfil, irmão de Betinho. (SANTOS; MORAES; COELHO, 1992)

47 A FSESP organizou treinamentos em hanseníase e doenças sexualmente transmissíveis para as suas unidades, iniciando pelo Centro de Referência Alfredo da Matta, em Manaus, com os médicos Adele Benzaken e José Carlos Sardinha. (OLIVEIRA, 2008) 
FIGURA 1 - Recorte do Regimento especial da 8 a Conferência Nacional de Saúde e Cartaz Aids e a Constituinte

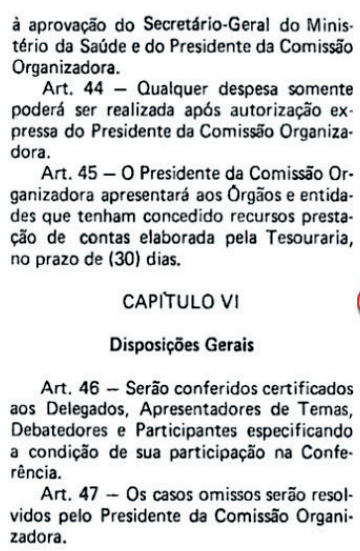

8ạ CONFERENCIA NACIONAL DE SAÜDE TEMARIO

Temas Básicos

1 - Saúde como Direito Inerente à Cidadania e à Personalidade

2 - Reformulação do Sistema Nacional de

Saúde

3 - Financiamento do Setor Saúde

Temas Especificos

1 - Saude e Trabalho

2 - Vigilância Epidemiológica (grandes en

demias, doenças evitáveis por imunização,

AIDS)

3-Saúde e Sistema Ecológico

4 - Saúde, Produção e Distribuição de Ali-

mentos

5 - Niedicamentos e Imunobiológicos

6. Saúde-Ora

7 - Sangue e Hemoderivados

8 - Reproduçäo Humana

9 - Práticas Alternativas de Saúde

10 - Recursos Humanos

11 - Saúde e Políticas Sociais

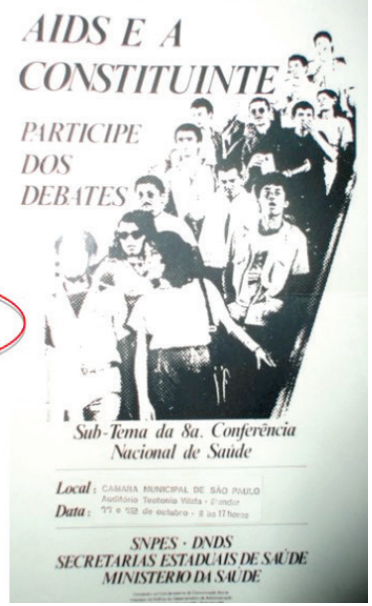

Fonte: Esquerda: Conferência Nacional de Saúde (1986, p. 408). Direita: Brasil (1986a).

No início, os hematologistas e o Estado mantiveram um discurso de minimizar o problema. Os primeiros contemporizando que o principal problema para os hemofílicos "não é a transmissão da doença pelo sangue, mas sim a falta de sangue". (NO RIO..., 1985, p. 13) O segundo alegando falta de recursos ou contestando o tamanho da amostra utilizada no relatório da Divisão Nacional de Sangue e Hemoderivados, que sugeria que 70 a $84 \%$ dos hemofílicos do eixo Rio-São Paulo estariam contaminados. (PROGRAMA..., 1987; TEIXEIRA..., 1985) Contudo, o Boletim Epidemiológico n. 5 de 1987 trazia recomendações, ainda que insuficientes para o controle do sangue no país, tais como: não aceitar candidatos à doação remunerada, nem provenientes de casas de detenção ou colônias de recuperação de drogaditos ou expostos a fatores de risco; realizar busca de manifestações da doença ao exame físico; implantar sistema de autoexclusão, entre outros. ${ }^{48}$

As associações específicas de luta contra a aids, que surgiram a partir de 1985, tiveram papel determinante para a regulamentação do controle 
do sangue e hemoderivados no Brasil, constituindo em 1988, o comitê "Pacto de Sangue", uma iniciativa que congregava diversas entidades que ofereciam apoio jurídico na promoção de ações contra o Estado, hospitais e clínicas onde havia ocorrido contaminação. (SANTOS; MORAES; COELHO, 1992) A Associação Brasileira Interdisciplinar de Aids (Abia), tendo o sociólogo Herbert de Souza, um hemofílico, na sua direção, realizou uma mobilização que tinha como slogan: "Salve o sangue do povo brasileiro”. As principais condições para a organização dessa mobilização foram: a importância da questão do sangue para o movimento sanitário, a participação de sanitaristas no conselho diretor da Abia, a emergência da epidemia da aids, assim como as discussões e elaboração de uma nova constituição. (PARKER; TERTO JUNIOR, 2001) Da mesma forma, Paulo Bonfim, do Gapa, envolveu-se nessa questão. (CONTRERA, 2000) Ambos inclusive foram a Brasília para fazer lobby junto à assembleia constituinte.

Em 25 de janeiro de 1988, a Lei n. 7.649 estabeleceu a obrigatoriedade do cadastro dos doadores de sangue e da realização de testes de laboratório para hepatite $\mathrm{B}$, sífilis, doença de Chagas, malária e aids. O projeto de lei foi apresentado em outubro de 1985 pelo Senador Gastão Muller, do PMDB do Mato Grosso, e teve como relator o deputado Carlos Sant'Anna. A assinatura da lei aconteceu dias após a morte do famoso cartunista Henfil, em 4 de janeiro de 1988. Sua morte levou a inúmeras manifestações e protestos em todo o país, de modo que a lei ficou também conhecida como "Lei Henfil." (BRASIL, 1988b) Esta lei foi regulamentada pelo Decreto 95.721, de 11/02/1988.

Em outubro, a nova constituição proibiu a comercialização do sangue e hemoderivados no país. (BRASIL, 1988a, Art. 199, §40) Tiveram importante papel nessa discussão na assembleia constituinte Sérgio Arouca, então presidente da Fiocruz, e o deputado federal Carlos Sant'Anna fazendo a defesa do dispositivo nos dois turnos de votação. Carlos Sant'Anna, embora fosse chefe do governo na Câmara dos Deputados, fez a defesa na condição de médico, contrapondo-se à posição do então Ministro da Saúde, Borges da Silveira. (SOUZA, 1988) A partir daí, o Ministério da Saúde elaborou as normas técnicas para a hemoterapia no país, através da Portaria n. 721 de 11/08/1989. Contudo, o projeto de lei para regulamentação desse parágrafo da constituição foi apresentado em 1991, pelo 
deputado Roberto Jefferson, do PTB do Rio de Janeiro, mesmo tendo regime de tramitação de urgência, apenas dez anos depois, em 2001, foi aprovada a Lei 10.205, que regulamentou a coleta, processamento, estocagem, distribuição e aplicação do sangue, componentes e derivados e proibiu o comércio desses materiais no Brasil. Pelo envolvimento do sociólogo Herbert de Souza nessa luta, a lei é conhecida como "Lei do Sangue" ou "Lei Betinho". (BRASIL, 2001b)

\section{A construção de uma identidade: a saída da dermatologia sanitária}

A concepção de Fabíola Nunes e Maria Leide acerca da posição do programa na estrutura do Ministério divergia daquela defendida por Lair Guerra, que considerava que o programa de aids ao interior da Divisão Nacional de Dermatologia Sanitária (DNDS) ficava limitado à dermatologia e que esse deveria se dissociar da divisão para ampliar seu leque de ações. Fabíola Nunes e Maria Leide de Oliveira consideravam que para antes desse desligamento seria necessária uma negociação com a Sociedade Brasileira de Dermatologia. (E10) Essas divergências traduziam disputas entre agentes do campo médico (Fabíola Nunes e Maria Leide), preocupadas com as disputas também desse campo, e uma agente do espaço aids (Lair Guerra), um espaço emergente que começava a se consolidar e buscar uma certa autonomia.

Ao final de 1986, havia discordâncias também entre a secretária Fabíola Nunes e o ministro Roberto Santos acerca da situação sanitária do país. Para o ministro, o Brasil estava respondendo bem ao avanço da epidemia e estava adotando providências para reduzir a sua incidência. (SECRETÁRIA..., 1986) Na visão de Fabíola, Roberto Santos “estava contra a reforma sanitária" (E10) e o avanço da aids evidenciava as fragilidades do setor de saúde e sua incapacidade de resposta à doença. A situação teria se agravado com uma ocorrência relacionada à campanha de vacinação contra o sarampo, devido a declarações de Fabíola Nunes à imprensa que desagradaram o ministro. Sua exoneração, contudo, ainda foi adiada para depois da visita de Jonathan Mann, diretor do Programa 
de Aids da OMS, ao Brasil em 1987, ${ }^{49}$ em função da nomeação de Carlos Sant'Anna como líder do governo na Assembleia Nacional Constituinte. (E10) Fabíola foi exonerada em 12 de fevereiro. (ATÉ MOSCAS..., 1987)

Durante a visita, Mann avaliou o programa brasileiro como "completo para 1987" e considerou que a campanha de prevenção proposta pelo Ministério da Saúde era "verdadeiramente histórica”, elogiando sua clareza e objetividade. (CAMPANHA..., 1987, p. 12)

Com a saída de Fabíola Nunes da Secretaria Nacional de Programas Especiais de Saúde (SNPES) no final de 1987, o Ministro Roberto Santos, seguindo a sugestão de Lair Guerra, criou a Divisão Nacional de DST/Aids (E10; E26) (OLIVEIRA, 2008), de forma que, sob a gestão de uma biomédica, o Programa saiu da DNDS, ganhando maior autonomia em relação à Dermatologia Sanitária, uma especialidade médica, e construindo, na visão de Pedro Chequer, um “modus operandi próprio.” (E27) s0 $^{50}$

Ainda que a separação tenha acontecido em 1987, foi oficializada apenas em 1988, através da criação da Divisão Nacional de DST/Aids, sob a direção de Lair Guerra, que permaneceu até março de 1990 (E15; ${ }^{51}$ E27), início de um novo governo. A Divisão foi transferida da Secretaria Nacional de Programas Especiais de Saúde (SNPES) para a Secretaria Nacional de Ações Básicas de Saúde (SNABS) e a sua criação era avaliada pelo Ministro Roberto Santos como uma valorização do Programa Nacional.

É interessante notar que, naquele período, a imprensa ainda tratava a aids de forma sensacionalista, alimentada pelo incipiente conhecimento acerca da doença pelo campo médico. Na mesma notícia o jornal Folha de São Paulo divulgava três assuntos relacionados à aids: uma fala do médico Ricardo Veronesi no congresso de infectologia que acontecia em Curitiba acerca de pesquisas realizadas na África que supunham a transmissão do

49 O Diretor do Programa de Aids da Organização Mundial de Saúde esteve no Brasil entre ze 4 de fevereiro de 1987, à convite do Ministro Roberto Santos, acompanhado de Ronald St. John, coordenador do Programa de Análise de Situação de Saúde e suas Tendências, da OPAS, e Fernando Zacharias, coordenador do Programa de Aids da América Latina, OPAS.

50 Entrevista concedida por E27, médico sanitarista, em Brasília, DF, em 3 de agosto de 2011.

51 Entrevista concedida por E15, secretária do Departamento de DST, Aids e Hepatites Virais do Ministério da Saúde, em Brasília, DF, em 4 de agosto de 2011. 
vírus HIV através de mosquitos; a exoneração de Fabíola Nunes e a criação da Divisão de DST/Aids; e por fim o posicionamento da Conferência Nacional de Bispos do Brasil (CNBB) acerca da campanha de prevenção do governo federal..$^{2}$ Contudo, a manchete concentrava-se no primeiro assunto. Essa ênfase no aspecto informado por um médico infectologista, professor da USP também aponta para a dominância e reconhecimento do saber médico como aquele que detém a autoridade sobre a doença.

Dadas as possibilidades terapêuticas do período e a insuficiência de recursos, a gestão de Lair Guerra pautou-se principalmente em iniciativas visando a estruturação do programa e a prevenção da aids. As atividades a serem implementadas no país passaram a ser normalizadas de forma centralizada, invertendo a sua relação com os estados que até então formulavam e executavam seus programas específicos. (TEIXEIRA, 1997) Além disso, a gestão de Lair Guerra foi marcada pela crítica das organizações não governamentais, em especial a Abia e o Gapa, principalmente no que tange à assistência aos doentes, às campanhas de mídia produzidas, e ao discurso do ministério, visto pelos grupos como normativo e medicalizador:

[...] Não há estímulo à pesquisa. Não existe um programa real de assistência ao doente. Não háleitos, médicos, medicamentos, hospitais. Não há um programa consistente de educação e informação. Frente a essa omissão, uma campanha foi montada agora, decidida em gabinetes e escritórios de agências de publicidade, oferecendo ao público uma cara da Aids e a fisionomia de um país desgovernado. Nesta campanha, a única informação realmente clara é a de que o Governo não conhece nem este país, nem as responsabilidades que tem diante dele. Só mesmo o mais completo desinteresse pela saúde pública pode justificar a sucessão de equívocos que modelou esta campanha. (QUEM SEMEIA..., 1988, p. 1)

As campanhas de televisão do Ministério da Saúde sobre Aids não informam a população, geram dúvidas sem darem a resposta imediata para esclarecê-las, e gastam muito dinheiro. [Paulo Bonfim, presidente do Gapa-SP] mais adiante neste capítulo. 
$[\ldots]$

Nós já atendemos diversas pessoas com dúvidas sobre o que ouviram e viram na TV. Temos que fazer uma verdadeira lavagem cerebral para ensiná--las corretamente. [Eduardo de Carvalho, presidente do Gapa-MG] (EM JUNHO..., 1988, p. A-20)

[...] O tipo de mensagem que jogamos é: a gente não é médico, não é nada, a gente é como vocês, pessoas que estão preocupadas com a aids, a gente foi aprender um pouco e está tentando transmitir o que aprendeu. Usem a sensibilidade, conheçam os fatos. O nosso lema é: estar informado éa melhor prevenção. Então, informem-se, leiam tudo, mas leiam com consciência crítica. A gente tem apelado muito para a sensibilidade das pessoas, para que elas próprias decidam o que é bom ou não é, para elas, e não deixem decidir os médicos, o presidente, o Ministério da Saúde, o que é, bom para a saúde dessas pessoas. O governo já decide tantas coisas da sua vida: o seu salário, a sua habitação. . . Agora vai decidir também a sua cama? Você é que tem que garantir o direito de decidir isto. [Arthur do Amaral Gurgel, presidente do Gapa-RJ] (O GAPA..., 1988, p. 10)

Em 1987, a primeira campanha governamental resultou do trabalho do grupo composto pelo publicitário Jorge Borges, a diretora da DNDS Maria Leide, o vice-diretor do Gapa-SP Paulo César Bonfim, e o general Aureliano Pinto de Moura, da Divisão da Saúde do Exército, e teve como slogan “Aids, você precisa saber evitar!”. (GOVERNO..., 1987, p. A-12) A campanha contava com cartazes (Figura 2) e chamadas de meio minuto na TV, abordando temas como uso de preservativo, camisa de vênus, nas relações sexuais, o risco de contaminação através do compartilhamento de seringas, ressaltando que a aids não se transmite na convivência diária com o doente e incentivando a doação de sangue. Ou seja, o foco da propaganda era na prevenção. Vale destacar que, até mesmo nas campanhas publicitárias, havia referência ao medo e à morte relacionados à aids. A seguir estão transcritos os textos de algumas dessas chamadas.53

Todos os vídeos analisados e transcritos estão disponíveis no sítio eletrônico do Departamento de DST, Aids e Hepatites Virais do Ministério da Saúde: <http://www.aids.gov.br/pagina/videos>. Acesso em: out. 2012. 
FIGURA 2 - Cartazes da campanha Aids, você precisa saber evitar
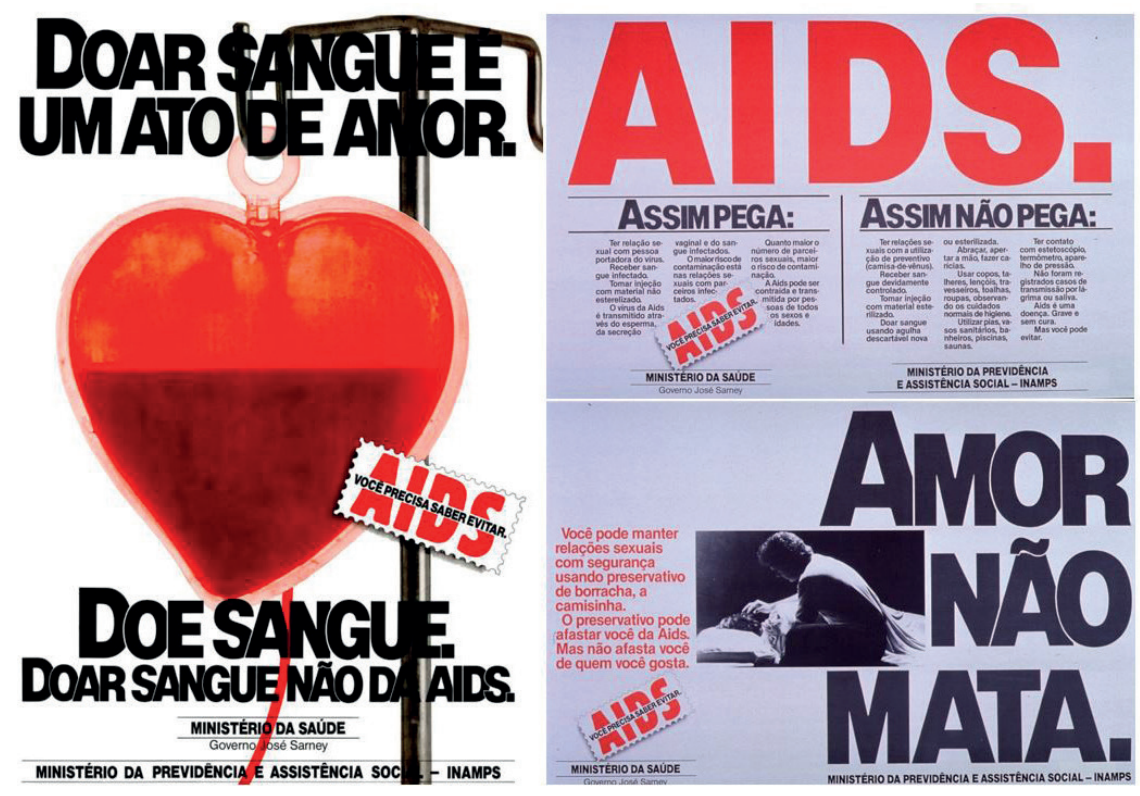

Fonte: Brasil (1987). 
A aids é uma doença que passa de pessoa para pessoa através do esperma e do sangue contaminado. A aids não tem cura e mata. Só tem uma maneira de evitar que esta epidemia continue: a prevenção. Nas suas relações sexuais use a camisa de vênus. A camisinha pode afastar você da aids, mas não afasta você de quem você gosta. (AIDS..., 1987c)

O vício da droga é uma agressão para a saúde e a agulha da seringa que passa de mão em mão pode estar contaminada com o vírus da aids. Se você não está conseguindo largar o vício, procure ajuda. Evite seringas usadas, assim pelo menos de aids você não morre. (AIDS..., 1987d)

De todos o sintomas da aids o que causa mais dor é a solidão. $\mathrm{Na}$ maioria dos casos a família e os amigos se afastam do doente da aids por medo e preconceito. Aids não se pega convivendo com o doente. Aids não se pega com abraço. Aids não se pega com afago e com afeto. Enquanto a cura não vem, carinho é o melhor tratamento. Aids você precisa saber evitar! (AIDS..., 1987a)

O medo da aids está assustando alguém muito importante para a saúde do país, o doador de sangue. Não tenha medo, não se pega aids doando sangue desde que a agulha seja descartável ou nova ou esterilizada. Doe seu sangue. Só assim você impede que a vida de muitas pessoas se esvazie nos hospitais. (AIDS..., 1987b)

Além dessas, havia peças publicitárias de um minuto com os atores Irene Ravache e Paulo José, esclarecendo sobre a forma de transmissão do vírus, sobre a doação de sangue e os riscos de contaminação através da transfusão de sangue e do compartilhamento de seringas.

A CNBB considerava que a campanha exaltava "práticas sexuais contrarias à natureza" e sugeriu a substituição dos termos "camisa de vênus" e "coito anal", por "preservativo" e "relação sexual" respectivamente. Na visão de Paulo Roberto Teixeira, da SES-SP, do médico infectologista Vicente Amato Neto, e de Paulo Cesar Bonfim, do Gapa, a aids era um problema sério e questões de ética e moral não poderiam impedir ações para evitar o crescimento da doença no país. A informação veiculada na mídia era de que haveria "censura prévia para evitar choques com a igreja". 
(PASTORAL..., 1987, p. A-16) De fato, esses foram os termos utilizados na campanha, como pode ser observado nos trechos citados anteriormente e aparentemente, o uso do termo "coito anal" referia-se ao primeiro filmete: Campanha Aids, você precisa saber evitar - dominó 1987, que, de acordo com a reportagem da Folha de São Paulo, inicialmente teria a imagem de nádegas nuas para reforçar a questão do sexo anal.

As críticas, contudo, surgiram principalmente em reação à campanha de 1988, que tinha o slogan: “Aids, pare com isso!”, para a qual foram elaborados dois vídeos com cerca de um minuto cada: no primeiro, uma aeromoça, antes da decolagem, explicava para os passageiros os meios de transmissão da aids e como se prevenir e usar a camisinha:

Senhores passageiros, bem vindos à bordo. Atenção para essas instruções que podem salvar sua vida nessa viagem: em suas relações sexuais, qualquer que seja o parceiro, use sempre camisa de vênus ou faça o seu parceiro usar; e se, por alguma razão, você tiver que tomar uma injeção, nunca use seringas e agulhas de outras pessoas, tenha certeza de que a seringa saiu diretamente de uma embalagem original, esterilizada e descartável; se precisar de uma transfusão de sangue, por qualquer motivo, exija o teste anti-aids no sangue que você vai receber. Lembre-se a aids mata sem piedade. Não deixe que essa seja a última viagem de sua vida. Aids, pare com isso! (AIDS..., 1988a)

A mensagem responsabilizava os indivíduos inclusive por medidas que fugiam a sua alçada, como o controle da qualidade do sangue. Ou seja, deslocava a responsabilidade do Estado para as pessoas.

No segundo, enquanto o texto era lido por um narrador, imagens da vida noturna de uma cidade eram alternadas, mostrando principalmente mulheres, e alertando aos perigos da noite, em especial a aids:

A noite tem alegria, tem diversão, tem amor, mas tem também muitos perigos. O maior deles chama-se aids. É uma doença que mata sem piedade. Ela é transmitida pelo sexo, pelas seringas e agulhas contaminadas e pelas transfusões clandestinas de sangue. Não dá para saber quem é e quem não é portador da doença. Quem vê cara, 
não vê aids. Use sempre camisa de vênus, qualquer que seja o seu parceiro sexual e se por alguma razão tiver que tomar uma injeção, nunca use seringas e agulhas de outras pessoas. Lembre-se de que a aids é uma doença mortal que está se alastrando cada vez mais. Depende de você, de todos nós, interromper esta triste ameaça. Não permita que esta seja a última viagem da sua vida. Aids, pare com isso! (AIDS..., 1988b)

No texto Onze críticas a uma campanha desgovernada (1988), a Abia classificava a campanha nacional de:

a. errada porque afirmava que deveria usar preservativo em todas as relações sexuais, o que a associação considerava que transformava o sexo em transmissor de culpa e medo;

b. hipócrita porque dizia que as pessoas deviam se cuidar para não receber sangue clandestino, quando essa era uma responsabilidade do governo;

c. irresponsável porque não estava vinculada a outras ações de saúde coletiva;

d. mentirosa porque falava em controle do sangue, mas não adotava as medidas contra os comerciantes de sangue;

e. falsa porque transmitia informações truncadas devido aos limites impostos pelas barreiras ideológicas e por disfarçar o descaso e a incompetência;

f. preconceituosa porque personalizava a doença em uma mulher, sendo machista;

g. alarmista porque apresentava informações parciais;

h. simplista porque apresentava uma uniformização simplificadora e só atingia um público anteriormente informado;

i. obscurantista porque era "elaborada através de sofisticadas fórmulas metafóricas";

j. elitista porque era dirigida a um público urbano e mais educado; e 
k. inútil porque a aids era um problema sério demais para ser tratada com filmetes e anúncios curtos.

Essa visão contudo tinha opositores. Por exemplo, na opinião de Luiz Mott, do GGB, a Abia privilegiava uma "perspectiva hemofílica” na abordagem das questões relacionadas à aids, em detrimento dos demais grupos.

[...] Rotular de 'errada' a campanha somente por que nalguns cartazes aconselhou o uso dos preservativos em 'todos' relações sexuais, é flagrante parcialidade do analista, pois em questão de vida ou morte, é melhor pecar pelo excesso do que pela falta de informações e cuidados. Dizer que o governo não está fazendo nada contra a Aids, é outra inverdade, pois por mais tardia, tímida e locunosa, a campanha governamental tem surtido palpáveis resultados na conscientização de amplas camadas sociais, sobretudo no tocante à profilaxia da Aids. Chamá-la de preconceituosa é uma injustiça, pois esse tem sido um dos aspectos mais positivos dessa campanha, que evita estigmatizar e mesmo citar os chamados 'grupos de risco', desmascarando preconceitos sociais contra os aidéticos. Apelidar a campanha de obscurantista por que usa fórmulas metafóricas sofisticadas, é outra mentira, pois malgrado a censura dos Bispos, as mensagens e imagens são bastante claras e compreensíveis por qualquer pessoa. Concluindo a avaliação feita pela Abia da Campanha do Governo contra a Aids peca pela intolerância, injustiça, falta de objetividade e derrotismo. [...] Rotular a Campanha de alarmista e estimuladora do pânico reflete grave desconhecimento por parte da Abia dos sentimentos e reações populares às informações prestadas pelo Governo, Convivendo semanalmente com centenas de homossexuais que frequentam a sede do Grupo Gay da Bahia, tenho elementos empíricos para confirmar que lastimavelmente a campanha não tem sido mais agressiva e dramática do que gostaria, pois boa parte dos gays baianos que frequentam o GGB continuam a fazer sexo na mesma frequência e risco como se a Aids não os ameaçasse, Entre os gays conscientes, há tranquilidade, entre os irresponsáveis. Indiferença. Onde está o pânico aludido pela Abia? A meu ver, falta maior contato dos teóricos do Abia com o povo brasileiro. [...] (MOTT, 1988, p. 12) 
Foram identificadas três concepções acerca das campanhas preventivas governamentais: uma concepção técnica, expressa principalmente pelos agentes do campo burocrático; uma concepção técnico-científica, que aparece na fala de agentes do campo científico; e uma concepção política, expressa principalmente pelos agentes do subespaço militante, mas também por agentes de outros subespaços com trajetória militante no movimento sanitário ou na luta pela redemocratização do país.

QUADRO 5-Síntese das concepções acerca da prevenção e das campanhas preventivas governamentais entre os agentes entrevistados

\begin{tabular}{|c|c|c|}
\hline SE & Concepções & \\
\hline \multirow{5}{*}{ 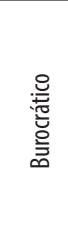 } & \multirow[t]{4}{*}{ Técnica } & Concepção asséptica do sexo \\
\hline & & Defesa do discurso sobre a gravidade da doença apoiado em argumentos médicos \\
\hline & & Defesa da campanha voltada para grupos de risco \\
\hline & & Oposição a uma visão limitada da prevenção \\
\hline & \multirow[t]{10}{*}{ Política } & Responsabilização da mulher na prevenção \\
\hline \multirow{8}{*}{ 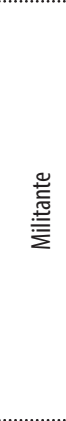 } & & As campanhas associavam a aids à morte, aos gays e a promiscuidade \\
\hline & & Oposição às campanhas específicas visando evitar a responsabilização dos gays \\
\hline & & Responsabilização dos gays, promiscuidade relacionada ao homossexualismo \\
\hline & & Falta de diálogo com a sociedade \\
\hline & & Prevenção restrita a campanhas, não articulada com assistência \\
\hline & & Crítica ao uso de termos científicos \\
\hline & & $\begin{array}{l}\text { Imposição de barreiras (pelo poder público e pela sociedade) para implementação de ações } \\
\text { inovadoras como a troca de seringas }\end{array}$ \\
\hline & & $\begin{array}{l}\text { Oposição de agentes do movimento homossexual à visão das lideranças soropositivas (disputa } \\
\text { interna) }\end{array}$ \\
\hline \multirow{2}{*}{ 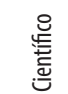 } & & Ausência de articulação com assistência \\
\hline & Técnico-científica & Defesa da campanha voltada para grupos de risco \\
\hline
\end{tabular}

Fonte: Elaborado pela autora.

Essas concepções acerca das campanhas governamentais evidenciavam as questões em jogo no espaço aids. (Quadro 5)

- A oposição às campanhas específicas voltadas para os denominados "grupos de risco," visando a não discriminação desses grupos foi um consenso inicial entre os representantes dos diferentes subespaços. Contudo, apesar de considerarem essa uma estratégia importante naquele momento, alguns entrevistados dos campos científico e 
burocrático a avaliaram negativamente, considerando que os estudos têm evidenciado, de fato, uma maior prevalência da infecção por HIV nesses grupos e a necessidade de um trabalho específico;

- A ausência de articulação com outras ações, seja assistenciais ou preventivas, limitando a prevenção às peças publicitárias e à distribuição de preservativos;

- A culpabilização dos homossexuais pela doença, evidenciada em um discurso que relaciona a promiscuidade à homossexualidade, como se não houvesse práticas sexuais perigosas para infecção por HIV entre heterossexuais, ou seja, as mulheres seriam vítimas, por exemplo, um entrevistado cita que falava-se em "suruba" entre homossexuais, mas não se falava de "swing" ou troca de casais entre heterossexuais;

- A incapacidade do Estado em fazer prevenção voltada para grupos específicos, transformando-a em uma atribuição do espaço militante (ONGs/Aids);

- A oposição à associação da doença à morte nas campanhas, especialmente por parte das ONGs/Aids e de soropositivos, que consideravam que estaria fomentando-se pânico e medo, bem como a discriminação, em contraposição aos que consideravam ser necessário um discurso claro e verdadeiro e que não associar a doença à morte seria escamotear a realidade;

- Existia por parte dos militantes também uma oposição ao uso de termos “científicos” pelo Ministério da Saúde, como preservativo em vez de camisa de vênus, considerada uma linguagem mais popular. Foi destacada também a dificuldade de implementação de estratégias devido a barreiras impostas pela própria sociedade, como aconteceu inicialmente com a tentativa de implementação de um programa de troca de seringas na cidade de Santos, São Paulo. Outro exemplo seria a interferência da igreja católica na censura prévia à campanha de 1987, como já relatado. 
Ou seja, havia um ponto de vista majoritário do movimento homossexual e das ONGs/aids, compartilhado também por técnicos progressistas que incorporava o cuidado contra o estigma e a discriminação, sem abrir mão da necessidade da mensagem técnica. Havia também um ponto de vista feminista, o ponto de vista médico asséptico e o ponto de vista médico-epidemiológico.

Nascimento (2005) considera que as campanhas governamentais sempre tiveram avanços e retrocessos desde o início da epidemia. Destaca a dificuldade em contemplar a diversidade de interesses envolvidos em um tema relacionado à sexualidade que suscita questões morais, políticas e religiosas, o que pode ser evidenciado em avaliações tão distintas provenientes de organizações do espaço militante: uma associação específica de luta contra a aids (Abia) e um grupo de homossexuais (GGB).

A necessidade de uma intervenção voltada para os grupos específicos, mais expostos ao risco de infecção pelo HIV e socialmente marginalizados, foi recomendação da Comissão Nacional de Aids na sua 5 a reunião (19 de janeiro de 1988). ${ }^{54}$ Prevaleceu entre seus membros a opinião de que a campanha deveria ser dirigida para a população geral, porém com ações para grupos específicos. Entre 1988 e 1989, o Programa Nacional elaborou o projeto "Previna - Prevenção e Informação sobre aids e outras DSTs". O projeto teve inicialmente como público-alvo profissionais do sexo, usuários de drogas e presidiários e, a partir de 1990, também garimpeiros da Amazônia legal, homossexuais e crianças e adolescentes em risco social. (CAMPOS, 2005)

O referido projeto não foi objeto de discussão específica na Comissão Nacional de Aids, mas a priorização dos grupos segue os temas das discussões e recomendações das reuniões seguintes da Cnaids, a saber: (BRASIL, 1994a)

a. Aids nos presídios, tema debatido na $4^{\mathrm{a}}$ reunião, realizada em 9 de outubro de 1987;

A ata da reunião do dia 19 de janeiro de 1988, diz que em votação a maioria optou por campanhas dirigidas à população geral, com ações para grupos específicos, porém não evidencia as discussões acerca do tema. 
b. Estratégia de trabalho com usuários de drogas, tema debatido na $6^{\mathrm{a}}$ reunião, realizada em 29 de fevereiro de 1988;

c. Aids e prostituição, tema da $8^{\text {a }}$ reunião, realizada em 2 de junho de 1988;

d. Crianças e adolescentes em situação de risco, tema da 11a reunião, realizada em 18 de abril de 1989; e

e. "Por consenso, a Comissão recomendou que a DN-DST/AIDS, desenvolvesse com maior ênfase projeto educativo dirigido a grupos de homossexuais", na $13^{\text {a }}$ reunião, realizada em 15 de agosto de 1989.

As estratégias do projeto Previna foram definidas a partir de uma série de reuniões com outros órgãos governamentais, universidades e organizações não governamentais e previam o treinamento de instrutores, produção de material informativo e distribuição de preservativo. O Previna foi implantado em seis estados: Rio Grande do Sul, São Paulo, Rio de Janeiro, Ceará, Bahia e Amazonas e no Distrito Federal, através de parcerias com ONGs. (CAMPOS, 2005)

Ela [Lair Guerra] criou o projeto Previna [...] que tinha como missão trabalhar em toda esfera nacional com 4 populações: população carcerária, populações de trabalhadores sexuais, população gay e usuária de drogas. E eu fui chamado por Dr ${ }^{a}$ Lair Guerra, logo depois de o Gapa-Bahia ter menos de 1 ano. [...] para ser o coordenador na região norte e nordeste do programa Previna nos presídios. Fiz um treinamento longo em São Paulo, no Carandiru, e depois eu era o responsável por toda a região norte e nordeste no Brasil. [...] para treinar todos os... Uma equipe de médicos, de profissionais paramédicos da população carcerária [...]. (E14) ${ }^{55}$

O Previna foi a primeira experiência mais formal de parceria entre o Estado e ONGs na prestação de serviços relacionados à aids. Os principais problemas para a sua implementação foram dificuldades no financiamento, em especial para a realização dos treinamentos e capacitações em abril de 2011. 
diversas regiões do país, e as divergências na linguagem a ser utilizada na elaboração do material didático, se seria uma linguagem mais técnica e científica, o que era defendido pelo Programa Nacional, ou uma linguagem mais próxima da cultura do público alvo, reivindicada pelas ONGs. (CAMPOS, 2005)

O repasse financeiro para estados e municípios foi realizado através da OPAS, tendo o Ministério como interveniente. O Previna foi descontinuado durante o governo Collor e retomado em 1992 no retorno de Lair Guerra ao Programa Nacional. (CAMPOS, 2005)

É importante ressaltar que se Lair Guerra não esteve desde o início da formação do programa, a sua chegada deu impulso a uma nova fase, contribuindo para a estruturação inicial do programa, a captação de recursos e o desenvolvimento de novas ações, voltadas, em especial, para a realização de campanhas de informação sobre a doença e a formação de uma comissão de experts, a Comissão Nacional de Assessoramento em Aids, atual Comissão Nacional de Aids (Cnaids).

Foi um período de construção da política nacional, baseada principalmente em ações de vigilância epidemiológica e medidas preventivas, no qual surgiu a primeira possibilidade de tratamento, a zidovudina (AZT), embora este medicamento apenas tenha sido disponibilizado na rede pública em 1989 por alguns Estados e em 1991 pelo Ministério da Saúde. A Comissão Nacional de Aids foi um importante espaço de definições técnicas e políticas a esse respeito, e, embora seu papel fosse consultivo, diversos documentos discutidos e propostos pela comissão formaram a base do discurso oficial. (PROGRAMA NACIONAL DE DST E AIDS, 2003)

Paralelo ao que acontecia no campo burocrático, a epidemia da aids mobilizou também agentes no campo científico.

\section{O isolamento do vírus no Brasil e as disputas do campo científico}

Em abril de 1985, a Fiocruz recebeu duas garrafas de cultura de HIV trazidas pelo casal Margueritte Pereira (Peggy) e Hélio Gelli Pereira. Ela, inglesa, diretora do Laboratório de Saúde Pública de Londres, ele, virologista 
brasileiro, naturalizado inglês, chefe de departamento de universidades inglesas. Foi esse material que permitiu o início dos trabalhos da adaptação da metodologia de diagnóstico sorológico já utilizado para Chagas e o desenvolvimento de kits diagnósticos para o HIV, criando a base para a triagem de bancos de sangue no país. O Brasil começou a realizar o diagnóstico através da técnica de imunofluorescência, visto que os bancos de sangue estavam equipados para realizar essa técnica utilizando como teste confirmatório o Elisa, distribuído pela OMS. (E4) (SANTOS; MORAES; COELHO, 1992) Como destacado por Pinell e colaboradores (2002), o início da realização de testes laboratoriais para diagnóstico da infecção pelo HIV, levou ao surgimento de uma nova categoria: a dos soropositivos, trazendo alterações para o quadro epidemiológico e na conformação do espaço aids, principalmente no espaço militante. No Brasil, contudo, até 2014, a vigilância epidemiológica trabalhava apenas com os casos confirmados de aids, contando apenas com estimativas para os soropositivos. (BRASIL, 2014a, 2014b) Se a figura do soropositivo não aparecia nas estatísticas, no espaço militante essas figuras começaram a ter um importante papel, em especial, no final da década de 1980.

Apenas em maio de 1987 o HIV foi isolado pela primeira vez no Brasil pela equipe coordenada pelo Dr. Galvão. ${ }^{56}$ (GALVÃO-CASTRO et al., 1987) Apesar desse não ter sido um fato científico importante - os países desenvolvidos já haviam isolado o vírus há cerca de 4 anos - , teve ampla divulgação pela imprensa, de modo que conferiu ao grupo de pesquisa um reconhecimento para além do campo científico e terminou por garantir novos financiamentos, funcionando como um importante capital simbólico. (GALVÃO-CASTRO et al., 1987; MOURA, 2005)

A equipe do Laboratório dirigido pelo Dr. Galvão era composta por Euclides Ayres de Castilho (epidemiologista), Jairo Ivo dos Santos (bioquímico), Claudio Ribeiro (imunohematologista), José Carlos Couto Fernandez (Biólogo), Vera Bongertz (bioquímica), Dumith Chequer Bou-Habib (Médico, Doutorando em Microbiologia da UFRJ, orientando de Bernardo Galvão) e Carlos Morel (Médico, Doutor em Biologia Celular, Diretor do Instituto Oswaldo Cruz). (GARCIA, 2011) A equipe era composta principalmente por jovens pesquisadores, recém-doutores, que voltavam ao país, outros como o próprio Galvão, com elevado capital científico nas áreas básicas, mas que ainda não tinham tanto prestígio. 
Como consequência, o Banco do Brasil solicitou um projeto para a construção de um Laboratório P $3 .{ }^{57}$ Avaliado inicialmente por um médico pneumologista como "não original", o projeto, no valor de 3 milhões de dólares, foi "engavetado" e só foi aprovado após intervenção do arcebispo do Rio de Janeiro, D. Eugênio Sales, junto a Camilo Calazans, então presidente do Banco do Brasil. Este projeto permitiu a construção do Laboratório Nacional de Saúde Pública em Salvador, o primeiro laboratório $\mathrm{P}_{3}$ da Fiocruz, não específico para aids, mas a partir do qual foi criada uma rede nacional de laboratórios para isolamento e caracterização do HIV no Brasil. (E4)

Com relação ao espaço aids no mundo, no subespaço científico, houve uma disputa pelo reconhecimento da autoridade científica pela identificação do vírus pelos grupos de pesquisadores do Instituto Pasteur, liderado pelo francês Luc Montagnier, e da Universidade da Califórnia, liderado pelo americano Robert Gallo. (CAMARGO JÚNIOR, 1994) No Brasil também observaram-se disputas pelo reconhecimento dos feitos científicos, ainda que esses, como já comentado, nem sempre recebiam grande importância científica internacional.

Essas disputas, algumas vezes, extrapolaram os limites do campo científico, e chegaram até as páginas dos jornais. Em 1988, por exemplo, a notícia da apresentação de um trabalho sobre detecção do vírus HIV-2

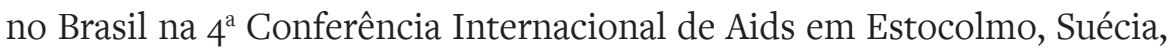
pelo médico da UFRJ, Eduardo Côrtes, que estava fazendo pós-graduação na Universidade da Califórnia (UCLA), EUA, gerou críticas do professor Ricardo Veronesi, que atribuía o mérito da descoberta a uma parceria entre a USP e a Universidade de Lisboa. (ALBUQUERQUE, 1988; VERONESI, 1988) 
Como se tratava de uma doença desconhecida, além dos médicos clínicos que atenderam aos primeiros casos, os pesquisadores das ciências básicas foram extremamente importantes na identificação do vírus, primeiro passo para o estabelecimento de medidas terapêuticas. Em sua maioria, eram jovens pesquisadores, em início de carreira, buscando se afirmar no campo científico, de modo que a aids surgiu como a possibilidade de independência científica de alguns recém-doutores, como Valéria Petri, ou pesquisadores em início de carreira, como Bernardo Galvão, por exemplo. Assim, as disputas geracionais, entre jovens pesquisadores e pesquisadores veteranos, bem como as disputas entre instituições, exemplificam as lutas desse subespaço: uma luta por reconhecimento dentro do campo científico do espaço aids, seja para alcançar ou manter uma posição de autoridade científica, ou mesmo uma posição de expert do Estado. (BOURDIEU, 2011)

Depois que o Ministério da Saúde me mandou um passaporte de serviço diplomático, sei lá o que é que era aquele passaporte lá, para eu ir representar o Brasil nos Estados Unidos, foi que começaram a me desdizer. É gozado. Aí o Dráuzio passou por mim 'Não liga não, que eles estão todos enciumados'. É assim para todo lado, não é? Ninguém consegue controlar essas coisas. Eu fui porque o Yunes indicou, ele me ligou, elefalou '[...] você vai representar o Brasil, porque eu indiquei você'. (E31)

Eles não aceitavam que não fosse a Fiocruz que fizesse, entendeu? E nós perdemos muita grana por causa disso. Eu consegui grants nos Estados Unidos. A UFRJ tinha um acordo firmado com a Fiocruz, tem até hoje, de colaboração: professor daqui vai prá lá, o de lá vem, pra cá. Se quiser. Funcionalmente. E o NIH ofereceu, convidei eles para fazerem juntos. O Ministério da Saúde não deu carta de que aprovava o trabalho. Não deu. E a gente ia fazer com eles. Convidamos formalmente eles para fazer. Mas como não foram eles que iam fazer, eles cancelaram. Dois milhões e meio de dólares. $(\mathrm{E} 7)^{58}$ 
Nessas evidências, verificam-se oposições tanto geracionais (Veronesi X Eduardo Côrtes, Veronesi X E31), bem como entre instituições (USP X UFRJ, USP X Escola Paulista de Medicina, UFRJ X Fiocruz).

Ao interior do campo médico, estava em jogo a relação de poder entre a recém-criada Infectologia, a Medicina Tropical e a Dermatologia. A Infectologia surgiu no Brasil em 1980, a partir da criação da Sociedade Brasileira de Infectologia, contrapondo-se à Medicina Tropical, com uma proposta de abranger as doenças infecciosas e parasitárias de forma diferenciada, incluindo todos os aspectos que envolviam as doenças infecciosas dentro da Medicina Interna e considerando que o termo Medicina Tropical não dava conta de uma epidemia como a aids, que não se restringia exclusivamente aos trópicos. (SBI..., 2005) Contudo, a Dermatologia, como identificou os primeiros casos, devido ao sarcoma de Kaposi, uma lesão de pele, e também pelo fato de abranger, àquela época, no Brasil, as DSTs, foi a especialidade da medicina que criou as bases para a elaboração da política de aids no país. Se nos EUA, os principais pesquisadores que se envolveram com a aids eram oncologistas, no Brasil, os oncologistas não tiveram um papel de destaque.

[...] Naquela época, eles achavam que uma dermatologista poderia atrapalhar a obra deles ou aquilo que eles pretendiam fazer. Então eles declaravam isso na televisão. Uma vez o Veronesi falou assim 'Dermatologista só serve para atrapalhar'. [...] Era muito mais difícil... Hoje não. Hojeénatural as pessoas aprenderem sobre isso, lidar com os medicamentos e tudo. (E31)

[...] como a aids começou com a epidemia de sarcoma de Kaposi, a oncologia nos Estados Unidos é que tomava conta da aids, da doença aids, compreendeu? E a Universidade da Califórnia era um dos maiores centro americanos de aids. O que a gente tinha de doentes, com sarcomas, linfomas, e era um centro de excelência, que fazia um monte de pesquisas, então, todos oncologistas. O Luc Montagnier [...] Ele era chefe da sessão de virologia tumoral do Instituto Pasteur. O Robert Gallo, o que era? Ele era do Instituto Nacional do Câncer Americano. (E7)

Os agentes dos campos burocrático, médico e científico sempre mantiveram uma relação importante com o espaço militante, inclusive alguns 
foram fundadores dos movimentos sociais envolvidos na epidemia e das associações específicas que surgiram com a conformação do espaço aids.

\section{O espaço militante}

Foi indiscutível a importância do movimento gay na elaboração das primeiras respostas à epidemia, sendo que alguns grupos, a exemplo do Grupo Gay da Bahia (GGB), até hoje realizam atividades relacionadas à prevenção da aids. A vinculação com os homossexuais, entretanto, reduzia a possibilidade de acesso a outros grupos devido ao preconceito por parte de determinados setores da sociedade. O próprio GGB, para dar continuidade às ações contra a epidemia da aids e ampliar a abrangência do público ao qual teria acesso, teve necessidade de criar uma organização específica, a qual compartilhava o mesmo espaço e membros que o GGB, mas que se desvinculava do movimento homossexual - Centro Baiano Anti-Aids (CBAA) ${ }^{59}$ Foi nesse sentido que surgiu a primeira associação específica de luta contra a aids, Gapa, em São Paulo.

\section{Grupo de Apoio e Prevenção à Aids - Gapa}

O movimento que levou à formação do Gapa teve início ainda em 1983. Em seu livro, Contrera (2000) afirma que as primeiras discussões surgiram em reuniões com o médico e professor Ricardo Veronesi, no Hospital das Clínicas da USP. Havia um descontentamento do público com o conteúdo das reuniões, consideradas exageradas, carregadas de preconceito e discriminação. (CONTRERA, 2000) A constituição do Gapa remonta à própria criação do Programa Estadual de Aids da SES-SP, haja vista ter

[...] em 87, fundamos o Centro Baiano Anti-AIDS, que eram as mesmas pessoas praticamente do GGB. Mas como para fazermos palestras, fazermos a situação de prevenção em ambientes oficiais ou particulares, em escolas, universidades, sindicatos, associação de bairro, a palavra Grupo Gay ainda provocava preconceito, então, nós achamos que era uma forma de diversificar e de camuflar a nossa atuação através do Centro Baiano Anti-AIDS e também a possibilidade de financiamentos nacionais e internacionais. (E2O) 
decorrido de reuniões promovidas por esse programa, ${ }^{60}$ realizadas nas instalações do Instituto de Saúde entre os anos de 1984-1985. (E3; E26)

As reuniões aconteciam às terças-feiras à noite e contavam com a participação de profissionais da SES-SP e pessoas da comunidade. O grupo Outra Coisa teve participação importante na divulgação dessas reuniões. As reuniões seguiam um roteiro acordado entre seus participantes: balanço da situação epidemiológica; atualização acerca do conhecimento sobre aids; ações promovidas pelo Estado para a prevenção, assistência e apoio às pessoas afetadas pela epidemia; esclarecimento de dúvidas; debate entre os participantes, moderado pela equipe do Programa, inclusive com críticas e sugestões ao trabalho desenvolvido pelo mesmo. ${ }^{61}$

Sempre chegavam novos participantes. Segundo o relato de E3, o ápice foi uma reunião realizada no Instituto de Saúde no início de 1985. Com objetivo de discutir a prevenção de riscos de infecção, foram apresentadas diversas imagens de lesões relacionadas à doença, o que causou muita comoção.

Eu ficava assim mais tranquila talvez, [...] porque eu não conhecia as pessoas que estavam ali, mas 90\% dos frequentadores da reunião conheciam os defuntos, as pessoas mortas. Na época, se passava muito vídeo, um pedaço da pessoa mostrando um sarcoma, um tumor. [...] Para mim era um pedaço, porque era um pedaço, mas tinha gente que reconhecia... 'Ai! Aliéa perna de meu amigo', [...] aparecia muito o rosto, mas tudo com sarcoma e via tudo já deformado. Mas os amigos reconheciam e então desmaiavam e gritavam. E a gente ficava assim... Eu, a Yara, a Otília não, porque a Otília trabalhava com isso, então, para ela era um outro olhar. Mas para mim e pra Yara... [...] Muito histerismo mesmo, eas reuniões, a bem da verdade, no

As reuniões começaram a acontecer alguns meses depois da criação do programa, e as reuniões públicas uma vez por semana, à noite, no nosso serviço. [...] eram muito concorridas, principalmente pela comunidade gay, mas também pessoas envolvidas no movimento de hemofílicos, no movimento de transfundidos, profissionais de Saúde Pública, pessoas de universidade. [...] e as pessoas que tomaram a iniciativa, no primeiro ano, praticamente, do Gapa, se reuniam no nosso espaço. Nós cedemos espaço, salas e facilidades de comunicação: correio, telefone etc., e foi o primeiro, digamos, apoio. [...] o Gapa nasceu dentro da instituição, na medida em que começou a se consolidar, e a se estruturar, foi procurar a sua sede própria, mas durante pelo menos um ano funcionou no nosso serviço. (E26)

61 Entrevista concedida por Paulo Roberto Teixeira, em São Paulo, em 5 de janeiro de 2016. 
início, elas mostravam esses vídeos... como é que você ficava, mas não tinha o que fazer. Então era só para dizer: 'Oh, você vai morrer assim'. (E3)

Essa afirmação também é reproduzida por Contrera (2000), tendo por base os depoimentos de dois fundadores do Gapa - Auréa Abbade e Claúdio Monteiro.

Um ponto de vista mais técnico é apresentado pelo então coordenador do Programa de Aids da SES-SP, E26, agente dos campos médico e burocrático:

É possivel que algumas pessoas que assistiam pela primeira vez aquela apresentação, como a própria Áurea Abade, reagissem com desconforto mas a imensa maioria já frequentava as reuniões fazia mais de um ano. [...] Houvesse ocorrido cenas tão dramáticas, certamente iriam para as páginas dos jornais, pois repórteres participavam regularmente dos eventos. [...]

A apresentação do quadro clínico incluía a projeção de slides demonstrativos das principais manifestações da doença. Após algumas reuniões, o Programa propôs suspender a projeção de slides, supondo que estas informações já estavam suficientemente difundidas. Os participantes rechaçaram a proposta, argumentando, entre outras razões, que novos frequentadores surgiam à cada semana.

As imagens eram cuidadosamente selecionadas de forma a evitar a identificação de seus portadores. Eventuais slides que mostravam o rosto de pacientes provinham de publicações, em geral internacionais. Guardo ainda hoje o material iconográfico utilizado, que está à disposição de quem tenha interesse em examina-lo. Os encontros se sucederam, sem interrupção, por todo o ano de l984 até meados de 1985 , quando os frequentadores mais assíduos decidiram se organizar em uma ONG e, assim nasceu o GAPA-SP.

Foi uma das experiências mais importantes de diálogo entre o estado e a comunidade já ocorrida na história da saúde pública brasileira, que requer ser registrada adequadamente.

Portanto são diferentes pontos de vista entre outros possíveis, que representam pelo menos dois grupos distintos, que não refletem todos os pontos de vista acerca desse evento específico, muito menos o conjunto da atuação do Programa Estadual de Aids da SES-SP. Mas ilustra a percepção 
de três agentes: uma advogada que estava indo pela primeira vez a uma reunião sobre o assunto, um sociólogo e um médico, todos com diferentes posições e tempos de inserção no espaço aids. Pontos de vista que não podem ser desconsiderados, mas que devem ser contrapostos aos demais pontos de vista possíveis, que não foi objetivo específico desse estudo, mas que uma investigação específica sobre a fundação do Gapa certamente daria conta.

Naquele dia, decidiu-se formar uma organização não governamental de base comunitária, com objetivo de, associada ao ativismo político, promover prevenção, informação e assistência a portadores de HIV/aids e seus familiares, ou seja, substituir o Estado em suas funções. (BARATA, 2006; CONTRERA, 2000) O Gapa foi assim criado em janeiro de 1985 e teve a sua ata de fundação registrada no dia 27 de abril de 1985. (CONTRERA, 2000) O Centro dos Hemofílicos de São Paulo, na pessoa de D. Vitalina Dias da Silva, teve papel importante no apoio à formalização do grupo, dividindo a experiência da sua instituição e orientando os primeiros passos a serem seguidos pelas duas advogadas do grupo, Áurea Abbade e Yara Aparecida de Arruda.

Como estava também atingindo os hemofílicos, ela fez parte no início com a gente. Os hemofílicos e os talassêmicos. Mas não com muita vinculação, porque eles tinham medo de se confundir ou de ter mais um estigma além do que já tinham. Não queriam ser os transmissores do HIV, então tinha uma participação mais de orientação. [...] Um modelo de contrato, modelo de não sei o que, modelo de ata... Isso foi durante a semana... Aísentamos... Primeiro que a gente já sabia como era o fundamento, quais eram as funções do Gapa, os objetivos, que isso já vinha sendo discutido há tempos. Aí nós fizemos uma adaptação disso para aqueles modelos que ela tinha nos dado. [...] (E3)

Entre os fundadores do Gapa havia profissionais da SES-SP, como Paulo Roberto Teixeira, Paulo Bonfim, ${ }^{62}$ Otília Simões Janeiro Gonçalves; ${ }^{63}$

62 Baiano, técnico em Patologia Clínica, militante do PT e candidato a deputado federal de 1990, participante no movimento da saúde através da Associação dos Funcionários do Hospital do Servidor Público Estadual - AFIAMSP e do Sindicato dos Funcionários da Saúde SINDSAÚDE, Coordenador do Programa Municipal de DST/Aids de São Paulo de 1989 a 1991, durante a gestão da prefeita Luiza Erundina. 
o antropólogo Edward MacRae; as advogadas Áurea Celeste da Silva Abbade e Yara Arruda; o publicitário e professor universitário Wagner Carmo Fernandes; o professor de História do Cinema da USP, Jean Claude Bernadet; o sociólogo Cláudio Monteiro; o jornalista Oilson Pedro Gomes; o economista Zilton Luis Macedo; o servidor público Luiz Carlos Munhoz; os artistas plásticos Jorge Schwartz, Mário Silvio Gomes e Hudnilson Urbano; e a ativista do movimento da saúde Neusa Cegali Cateasis. (CONTRERA, 2000)

Além da participação de agentes ligados à SES-SP e ao Programa Estadual de Aids, o Estado teve importante papel no financiamento do Gapa. Foi o Programa Estadual de Aids que garantiu estrutura para os primeiros meses da associação cuja sede provisória era no prédio da própria SES-SP. Ao mesmo tempo, o Gapa deu voz às críticas dos profissionais ligados ao programa, os representantes do Estado, os agentes do oficial, que muitas vezes não podiam denunciar publicamente os atos dos quais discordavam. (E3; E26) (CONTRERA, 2000)

O Gapa, que se constituiu com um perfil político-assistencial, foi fundamental na conquista de direitos dos portadores de HIV/aids, tendo participação ativa na Comissão Nacional de Aids desde seu início, bem como na formulação da legislação previdenciária para os portadores de HIV/ aids (ABBADE; BAIÃO, 2010; CONTRERA, 2000), tendo contribuído, através da advogada Áurea Abbade, para elaboração do texto que subsidiou a elaboração da Lei 7.670/88, que estende aos portadores de HIV/aids a concessão de licença para tratamento de saúde, aposentadoria, reforma militar, pensão especial, auxílio doença e pensão por morte aos seus dependentes. Paulo César Bonfim foi o idealizador da proposta e quem a levou para Lair Guerra em uma reunião. Lair encaminhou o pleito ao Instituto Nacional de Seguridade Social (INSS). (E3) Ou seja, a preocupação do Gapa era com os direitos, neste caso previdenciários, do portador de HIV/aids, e não apenas no âmbito da saúde, haja vista a proximidade estabelecida com os doentes e os ditos "grupos de risco". (FELTRIN, 1996; MARTINS, 1996) Além disso, foi a assessoria jurídica do Gapa que 
deu entrada nas primeiras ações contra o Estado para o fornecimento de medicamentos antirretrovirais. ${ }^{64}$

O Gapa sempre fazia corpo a corpo junto à comunidade gay e com outros grupos vulneráveis à aids em casas de show, boates, saunas e na Parada Gay. Chegou a ter uma casa de apoio, mas as dificuldades para manutenção da estrutura, mesmo com o apoio financeiro da SES-SP, num período de grande inflação, inviabilizou a continuidade da iniciativa. (CONTRERA, 2000)

O primeiro cartaz de prevenção à aids foi criado pelo $\mathrm{Gapa}^{65} \mathrm{e}$ foi duramente criticado pela igreja que considerava que ele disseminava ideias pecaminosas como sexo fora do casamento e masturbação. (CONTRERA, 2000; FATAL, 1988)

Era do movimento. A gente estava preocupado, queria alertar a população sobre a aids, ao mesmo tempo não queria levar uma mensagem repressiva. [...] alertar e lutar contra a repressão. E daí, eu vim aqui para Salvador e estava com Mott, que é um velho amigo meu, e lá no GGB ele tinha um cartaz americano. E esse cartaz americano dizia, eu não me lembro o que dizia exatamente, mas alguma coisa assim que 'você pode fazer tudo que sempre fez, mas tem que tomar cuidado'. Não sei se sugeria o uso da camisinha. Era um cartaz assim que tinha uma caricatura que era engraçadinha e que trazia uma mensagem não repressiva. Eu peguei esse cartaz e levei pra São Paulo e mostrei pra esse grupo de pessoas que estava se organizando. E daí a gente fez assim 'Vamos fazer um cartaz nosso'. E esse cartaz, surgiu. A mensagem principal foi eu que bolei. Era 'TRANSE NUMA BOA'. E daífoi o Darcy Penteado que elaborou o cartaz, que ele é artista plástico. O Jean Claude Bernadet, professor da USP, crítico de cinema. [...] e ele então, ele e o Darcy Penteado, depois, sentaram e bolaram mais ou menos o cartaz. Que era assim uma porção de palavrinhas. Boline, beije, acaricie, masturbe, não lembro, mas um monte de coisas que

64 A primeira liminar para fornecimento de antirretrovirais de última geração pelo Estado foi obtida por uma ação impetrada pela advogada Áurea Abbade, do Gapa, em nome da professora Nair Brito. (FELTRIN, 1996)

65 Outras iniciativas surgiram. No Rio de Janeiro, por exemplo, o Triângulo Rosa elaborou um informe sobre aids, que foi distribuído a todos que procuravam o grupo, sendo, portanto, sua circulação mais limitada. (FATAL, 1988) 
você poderia fazer. Assim, e em letras grandes 'TRANSE NUMA BOA'. Então esse foi o primeiro cartaz a ser feito no Brasil de prevenção a aids. (E8)

O cartaz estimulava o sexo seguro, ainda que esta não fosse a expressão usada àquela época. Trazia uma mensagem não repressiva, em oposição àquela que posteriormente foi adotada pelo Ministério da Saúde e destacava a possibilidade de manter o prazer mesmo frente à ameaça da aids.

O financiamento do Grupo veio de parcerias com a SES-SP, como já mencionado, a fundação Ford, e outras instituições, inclusive o Programa Nacional de Aids. (E3) (CONTRERA, 2000)

A partir da emergência do Gapa-SP, começaram a surgir outras associações específicas de luta contra a aids. Em 1986, surgem a Associação Brasileira Interdisciplinar de Aids (Abia), no Rio de Janeiro, e o Movimento de Apoio ao Paciente com aids (Mapa), em São Paulo, bem como foram fundados Gapas em diversas cidades/estados, como Minas Gerais, Rio de Janeiro, Paraná, Santa Catarina e Taubaté (1987); Baixada Santista, Bahia e Ribeirão Preto (1988); Rio Grande do Sul, Ceará, Itabuna e São José dos Campos (1989), Sergipe e Distrito Federal (1991). Vale destacar que os Gapas constituíram-se autônomos e independentes, mas compartilhando o nome e tendo um estatuto comum. ${ }^{66}$ (CONTRERA, 2000; GALVÃO, 2000)

\section{Associação Brasileira Interdisciplinar de Aids - Abia}

No Rio de Janeiro, em 1985, Herbert de Souza, o Betinho, sociólogo, militante contra a ditadura militar que havia retornado do exílio em 1979 com a anistia política, começou a reunir no Ibase um grupo de representantes dos movimentos sociais, médicos e pesquisadores para discutir a epidemia da aids. (PARKER; TERTO JUNIOR, 2001)

[...] essas reuniões se ampliaram em tamanho e passaram a atrair importantes líderes de movimentos sociais progressistas, como o advogado Nilo Batista, da Ordem dos Advogados do Brasil 
(OAB); o bispo D. Mauro Morelli; o antropólogo Rubem Cesar Fernandes, do Instituto de Estudos de Religião (Iser); médicos e cientistas como Walber Vieira, doutor em medicina e clínica geral, e Bernardo Galvão, da Fundação Oswaldo Cruz; representantes de entidades e grupos diversos como a Cruz Vermelha e o grupo gay Atobá; e o antropólogo Peter Fry, então representante da Fundação Ford no Brasil. (PARKER; TERTO JUNIOR, 2001, p. 15)

Álvaro Matida, médico epidemiologista do Programa de Aids da Secretaria de Saúde do Estado do Rio de Janeiro, que também participava das reuniões iniciais, apresentou Betinho ao médico Walter Almeida, que também passou a participar regularmente. Betinho e seus dois irmãos o cartunista Henfil, e o músico Chico Mário - eram hemofílicos. Henfil e Chico Mário já haviam se contaminado. Junto com Walter Almeida, Betinho resolveu criar uma organização não governamental, inspirado na International Interdisciplinary AIDS Foundation (IIAF). A psicóloga Silvia Ramos, que naquela época estava cursando o doutorado em Ciência Política no Instituto Universitário de Pesquisa do Rio de Janeiro (IUPERJ) ${ }^{67}$ ficou responsável pela formalização da instituição, através de um contrato de risco com Betinho, a mesma seria remunerada a partir do primeiro financiamento. A decisão formal de criação da Abia foi tomada no final de 1986, sendo seu estatuto registrado no dia 10 de abril de 1987. (PARKER; TERTO JUNIOR, 2001)

A Abia tinha por objetivo

promover o desenvolvimento de atividades sociais e científicas voltadas para a prevenção e o combate à Síndrome da Imunodeficiência Adquirida (AIDS), tais como estudos, pesquisas e projetos socioeconômicos, estudos sociopolíticos, formação de banco de dados, gerenciamento e interpretação de dados, preparo e divulgação de estudos e relatórios, boletins e publicações, por parte da própria organização ou através de terceiros e outras em Saúde Pública na ENSP/Fiocruz. 
atividades pertinentes a esse objetivo organizacional. (PARKER;

TERTO JUNIOR, 2001, p. 17)

Inicialmente, o Ibase fornecia a infra-estrutura necessária - telefone, fax, material de escritório etc. - ao trabalho da nova associação. O primeiro financiamento, de cerca de 5 mil dólares, foi conseguido junto ao Instituto Nacional de Assistência Médica da Previdência Social (Inamps), através de contato de Betinho com Hésio Cordeiro, médico sanitarista, militante da reforma sanitária e, à época, presidente do instituto. Para a obtenção do segundo financiamento, junto à Financiadora de Estudos e Projetos (Finep), ${ }^{68}$ estimado entre 100 a 200 mil dólares, foi fundamental o contato de Silvia Ramos com seu vizinho Reinaldo Guimarães, presidente da Finep e, assim como Hésio Cordeiro, militante da reforma sanitária. Ou seja, assim como aconteceu com o Gapa, foi a partir do financiamento estatal (Inamps e Finep) que a Abia obteve recursos para a sua estruturação inicial e em ambos os casos corroboraram a concretização desse financiamento agentes vinculados ao movimento sanitário. Mas foi com o financiamento assegurado pela Fundação Ford, da qual Peter Fry que fazia parte do conselho diretor da Abia, era representante no Brasil, que a associação conseguiu de fato se estruturar enquanto organização, tornando-se mais profissional, passando a remunerar alguns de seus membros por seu trabalho. (PARKER; TERTO JUNIOR, 2001; SOUZA, 2002)

Participavam do conselho consultivo da Abia Sérgio Luis Carrara, ${ }^{69}$ Peter Fry, Álvaro Matida, Peggy Pereira e Hélio Gelli Pereira. (PARKER; TERTO JUNIOR, 2001)

Como no Gapa, também havia agentes do campo burocrático que participavam da Abia, a exemplo de Álvaro Matida, também militante do movimento sanitário, mas esta se conformou principalmente com o objetivo de gerar informação, agregando um grande número de especialistas

A Finep é uma empresa pública vinculada ao Ministério da Ciência, Tecnologia e Inovação, criada 1967, que tem a missão de promover o desenvolvimento econômico e social do país por meio do fomento público à ciência, tecnologia e inovação em empresas, universidades, institutos tecnológicos e outras instituições públicas ou privadas.

69 Cientista Social pela Unicamp (1979-1982) e orientando de Peter Fry naquela época no mestrado de Antropologia Social da UFRJ. 
e com uma tentativa de distinguir o seu trabalho daquele desenvolvido pelo Gapa. A Abia seria mais política, enquanto o Gapa seria mais assistencialista. Silva (1999) descreve os grupos mais políticos como ativistas, enquanto os assistencialistas seriam aqueles que ofereciam serviços e atenção direta, assumindo o papel do Estado.

O Gapa tinha mais a perspectiva da advocacy, a Abia tinha uma concentração, uma expertise muito grande em dar informações e dar esclarecimentos para grupos especificos. (E29)

\section{[...] a parte da Abia era bem mais intelectualizada. (E31)}

Inicialmente, a Abia não tinha portadores do vírus na sua composição ${ }^{70}$ e sua relação com o movimento homossexual era menos evidente. Seus membros eram principalmente pesquisadores, médicos e profissionais de saúde. Era uma associação criada por um médico e um hemofílico, integrante de um dos grupos em risco, porém considerado como vítima da irresponsabilidade do Estado, ao contrário de homossexuais, profissionais do sexo e usuários de drogas injetáveis, que eram vistos como culpados pela sua contaminação. (PARKER; TERTO JUNIOR, 2001)

A Abia também teve importante papel na definição da política nacional de controle da epidemia, seja como representante na Cnaids, da qual se afastou em 1992 por divergências acerca do papel da comissão, seja com relação às campanhas educativas, sempre assumindo uma posição de oposição à subnotificação dos casos ou à insuficiência e descontinuidade da assistência. (AIDS..., 1988; ONZE..., 1988; PEDROSA, 1997; SOUZA, 1997) Para a Abia (PONTOS..., 1988, p. 7), "qualquer campanha de prevenção é uma CAMPANHA DE SOLIDARIEDADE” e deve ser baseada em um programa nacional de prevenção e controle da epidemia, elaborada com participação da sociedade civil, com a produção de "maratonas de informação, programas de horas, ${ }^{71}$ em horário nobre, onde se forneçam

O sociólogo Herbert de Souza, o Betinho, teve diagnóstico de aids depois da fundação da Abia.

71 Referindo-se a programas extensos de TV, em contraposição às chamadas publicitárias curtas, de cerca de meio minuto que compunham as campanhas governamentais. 
os dados necessários para que cada um entenda e decida" (PONTOS..., 1988, p. 7), fornecendo informações para que cada um pudesse entender e decidir, considerando as realidades locais e a diversidade da população brasileira, alertando e não alarmando a população como considerava que faziam as campanhas do programa nacional.

Herbert Daniel, que foi para a Abia convidado por Silvia Ramos em 1988, tornou-se rapidamente uma das principais vozes da instituição. Homossexual, com uma trajetória militante contra a ditadura e pelos direitos homossexuais, mesmo sem estar vinculado a grupos gays, foi exilado entre 1974 e 1981, sendo o último anistiado do país a regressar. Em 1989, descobriu-se soropositivo e fundou o Grupo Pela Valorização, Integração e Dignidade do Doente de Aids (Pela VIDDA), primeiro grupo criado por pessoas vivendo com HIV/aids no país e que assumiu um perfil político-assistencialista, mais próximo da forma de atuação do Gapa. (DIAS, 2012)

\section{Posições e disputas ao interior do espaço militante}

Com a entrada das associações específicas de luta contra a aids, houve mudanças no espaço militante. Se anteriormente esse espaço era dominado pelos grupos homossexuais, para os quais a aids era um tema transversal, um dos diversos problemas enfrentados pela comunidade gay, assim como para grupos de talassêmicos e hemofílicos, menos atuantes por não desejarem vinculação com mais um fator de estigma e discriminação. Os grupos específicos de luta contra a aids surgiram buscando se distanciar da causa homossexual e tendo como tema central o controle da epidemia da aids, a exemplo do Gapa e da Abia, passaram a assumir a posição dominante. Apesar do Gapa ser a primeira associação, a Abia rapidamente adquiriu um status dominante nesse subespaço devido ao corpo de experts que conseguiu agregar, o capital social de alguns membros do seu conselho consultivo e seu potencial para a captação de recursos, bem como a penetração de seus representantes nos meios de comunicação, em especial de Herbert de Souza e Herbert Daniel. Vale destacar que alguns agentes do espaço militante, como Betinho e Paulo Bonfim, assumindo a direção dessas instituições, conseguiram converter seu capital 
militante em capital político e exercer influência sobre os campos político e burocrático. São exemplos dessa influência o papel de Bonfim na legislação previdenciária aos portadores de HIV/aids e, principalmente, Betinho na legislação referente à questão do sangue e do acesso universal aos medicamentos para aids.

Da mesma forma, a entrada do grupo Pela Vidda, no início da década de 1990 no espaço militante, reforçou o discurso centrado no portador de HIV/aids, principalmente com a conformação de outros grupos com essa característica, como Grupo de Incentivo a Vida (GIV), em São Paulo, VHIVER, de Belo Horizonte (1993), a Rede Nacional de Pessoas Vivendo com HIV/aids (RNP+) (1994) e o movimento Patrocine a Vida, de Santos (1996). (CONTRERA, 2000; GALVÃO, 2000)

Considerando a proposta de Brown e colaboradores (2004) para a análise dos movimentos sociais em saúde, verifica-se que no subespaço militante do espaço aids existe a convivência das três categorias de movimentos:

a. Movimentos de saúde circunscritos a grupos específicos, representados pelos grupos de luta pelos direitos dos homossexuais, pelos grupos de profissionais do sexo e de mulheres;

b. Movimentos de saúde incorporados, no qual, além dos grupos de luta específica contra a aids, estão representados também os grupos de talassêmicos e hemofílicos, presentes principalmente nos anos iniciais da epidemia, quando o controle do sangue ainda era um problema; e

c. Movimentos de acesso a saúde, representados pelos agentes oriundos do movimento da reforma sanitária, que militavam também nas associações de luta contra a aids, não sendo a aids uma questão central para a reforma sanitária, mas bandeira de alguns agentes que tinham transito em associações específicas de luta contra a aids e também no movimento sanitário.

As disputas entre esses grupos ficaram bastante evidentes nos Encontros Nacionais de ONGs/Aids, os Enongs. A primeira reunião aconteceu em São Paulo, em 1987, reunindo os três Gapas existentes à época 
- São Paulo, Minas Gerais e Rio de Janeiro. Em 1990, no encontro de Porto Alegre, já contava com a participação de outras instituições, como GGB, Abia e Iser, quando foi proposta a criação de uma rede brasileira de solidariedade a ser discutida em um fórum ampliado em abril de 1990 na cidade de Santos. As disputas ao interior do espaço militante davam-se entre as associações de luta específica contra a aids e os grupos nos quais a aids apareceu como tema transversal - movimento homossexual, movimento de hemofílicos, renais crônicos e talassêmicos -, em especial os grupos homossexuais; e entre as associações específicas com posição mais política ou mais assistencial, com mais e menos recursos.

As principais disputas identificadas ao interior do espaço militante e na sua relação com os demais subespaços estão relacionadas a(o):

a. Financiamento, estrutura e articulação com o Programa Nacional de Aids, ONGs mais antigas, melhor estruturadas e com maior capacidade de captação de recursos eram denominadas "King-ongs" ou poderosas, enquanto as mais novas, eram consideradas pobres ou fracas; (E3) (CONTRERA, 2000)

b. Viver com HIV/aids - inclui-se apenas aqueles com HIV/aids ou se inclui infectados e não infectados que convivem com soropositivos; (GALVÃO, 2000)

c. Prevenção (Quadro 5), se o discurso incorporava ou não a discriminação e também uma mensagem condenatória aos homossexuais ou ao sexo; se pautada no medo ou na solidariedade, no viver com a doença; (E7; E2O)

d. Uso do termo técnico: homens que fazem sexo com homens (HSH), Apêndice C, para militantes homossexuais o termo é considerado uma "despolitização da homossexualidade", enquanto para outros militantes e profissionais da aids, o termo contribui para a inclusão de homens que têm práticas homoeróticas mas não se consideram homo ou bissexuais, bastante comum à realidade brasileira.

[...] afirmo que no Brasil (e talvez devido ao hipotético preconceito) a maioria dos homens que têm relação sexual com outros 
homens não se considera e não é considerada 'Homossexual'. Afirmo que o termo 'Homossexual' (ou seus sinônimos, todos pejorativos) é entendido (!) pela quase totalidade da população brasileira como referente a indivíduos que têm certos trejeitos afeminados e que são considerados marginais, sem vergonhas, ridículos, doentes, viciados, ligados à prostituição e ao crime [...]. (FATAL, 1988, p. 26)

Outro espaço onde eram tratadas as questões relacionadas à epidemia e que permite a identificação de disputas são as reuniões da Comissão Nacional de Aids.

\section{Comissão Nacional de Aids: a construção do discurso oficial}

Com a chegada de Maria Leide na DNDS em fevereiro de 1986, foi realizada uma reunião nacional do Programa Nacional de DST/Aids, sob a coordenação de Paulo Roberto Teixeira, do Programa Estadual de Aids de São Paulo, na qual foi traçado o primeiro plano de ação e foi criado um comitê assessor de aids, denominado "Comitê de grupos de risco". (OLIVEIRA, 2008)

O Comitêfoi histórico e coordenado por Paulo [Teixeira] inicialmente tendo grande ajuda de Jair Ferreira do Rio Grande do Sul, Lucia [Amaral], Eliana [de Paula] da SES-BA, Mirian, professores de DIP de várias universidades, Vicente Amato Neto, do Emílio Ribas, e os grupos de risco. [...] Uma das primeiras funções do comitê foi apoio na pressão por um orçamento que permitisse executar o plano traçado. (E24)

Com a chegada de Lair Guerra, a partir desse Comitê, foi criada a Comissão de Assessoramento em Aids, que se tornou responsável pela elaboração do discurso de autoridade com relação aos principais dilemas relacionados à epidemia da aids no país, quando ainda havia pouco conhecimento sobre a doença e não existia uma resposta terapêutica. A Comissão tinha caráter técnico-consultivo e como objetivos: assessorar o Ministério da Saúde em todos os aspectos relacionados ao controle da aids no Brasil; acompanhar a execução e participar da avaliação semestral do Programa de Controle da Aids; acompanhar no nível 
internacional a evolução das pesquisas relativas à aids; e assessorar a Divisão Nacional de Dermatologia Sanitária na divulgação das informações às Coordenações Estaduais do Programa. A portaria de criação da Comissão de Assessoramento em Aids indicava 18 representantes de diferentes órgãos e instituições, sendo sete membros natos: Conselho Federal de Medicina (CFM), Conselho Federal de Odontologia (CFO), Federação Brasileira de Hemofilia, Sociedade Brasileira de Hematologia e Hemoterapia, Colégio Brasileiro de Hematologia e Hemoterapia, Inamps, Grupo de Apoio e Prevenção à Aids; e representantes de 11 instituições que compunham a secretaria executiva: a diretora da DNDS, o diretor do Centro Nacional de Referência em Aids, os diretores dos Centros Nacionais de Referência das DST, e representantes do Prósangue, do Programa Nacional de Capacitação de Pessoal para Controle da Infecção Hospitalar, da Secretaria Nacional de Vigilância Sanitária, do grupo de Odontologia do Ministério da Saúde, da Divisão Nacional de Educação em Saúde, da Fiocruz, da Divisão Nacional de Epidemiologia e da Coordenadoria de Comunicação Social do Ministério da Saúde. Além de "sete personalidades de notório saber e reconhecida atuação no controle da aids, indicados pelo Ministério da Saúde" (BRASIL, 1986c), contudo não houve uma relação nominal de quem eram esses representantes e nem foram localizadas as atas das duas reuniões realizadas nesse período. (BRASIL, 1994a; PROGRAMA NACIONAL DE DST E AIDS, 2003)

A partir de 1987, a sua denominação foi modificada para Comissão Nacional de Controle da Síndrome da Imunodeficiência Adquirida (CNCSIDA) e a lista de membros passou a ser nominal, indicando a instituição de cada participante. Os 10 membros da comissão foram indicados pela equipe do Programa Nacional de DST/Aids, compondo um grupo de experts, todos médicos, à exceção de Lair Guerra, biomédica, e de Hélio Pereira Dias, assessor jurídico do Ministério da Saúde. (Quadro 6) Assim, houve um retrocesso no número de componentes e a exclusão do Gapa (BRASIL, 1987), o que indica um reforço do componente técnico-científico. 
QUADRO 6 - Membros da CNCSIDA, conforme portaria MS/GM n. 101 de 10 de março de 1987, e trajetórias profissionais

\begin{tabular}{|c|c|}
\hline Membro (Instituição) & Trajetória profissional \\
\hline $\begin{array}{l}\text { Lair Guerra de Macedo Rodrigues } \\
\text { (DN DST/Aids) }\end{array}$ & $\begin{array}{l}\text { Biomédica, especialista em Administração de Saúde Pública e DST pelos CDC (EUA), } \\
\text { mestrado e doutorado por universidades americanas na área de DST, professora da UFPB } \\
\text { e mais tarde da UnB, trabalhou na área técnica de Saúde da Mulher do MS, Coordenadora } \\
\text { da Divisão Nacional de DST/Aids. }\end{array}$ \\
\hline Antônio Carlos Gerbase (SES-RS) & $\begin{array}{l}\text { Graduado em medicina UFRGS (1974), na década de } 1980 \text { estava na Unidade de } \\
\text { Dermatologia Sanitária da SES-RS como supervisor do programa de doenças venéreas e } \\
\text { por volta de } 1996 \text { foi para a OMS. }\end{array}$ \\
\hline Antônio Paulo de Menezes Filho (Inamps) & $\begin{array}{l}\text { Médico, em } 1988 \text { era Vice-diretor de pesquisa e ensino do Hospital Evandro Chagas e } \\
\text { Assessor da presidência do Inamps. }\end{array}$ \\
\hline Euclides Ayres Castilho (Fiocruz) & $\begin{array}{l}\text { Médico com Residência e doutorado em Medicina Preventiva (USP), livre-docente (1976) } \\
\text { pela USP, docente do Departamento de Medicina Preventiva da USP (1968-1985) e } \\
\text { epidemiologista da Fiocruz (1985-1996). Entre } 1996 \text { e 2000, foi Coordenador substituto } \\
\text { da Coordenação Nacional de DST/Aids. }\end{array}$ \\
\hline Hélio Gelli Pereira (Fiocruz) & $\begin{array}{l}\text { Virologista brasileiro, com carreira na Inglaterra onde foi Chefe da Divisão de Virologia } \\
\text { do Instituto Nacional de Pesquisas Médicas e chefe de Departamento de Virologia em } \\
\text { universidade, após a aposentadoria na Inglaterra voltou ao Brasil, para a Fiocruz. }\end{array}$ \\
\hline Hélio Pereira Dias (Ministério da Saúde) & $\begin{array}{l}\text { Advogado, assistente jurídico do Ministério da saúde e assessor do ministro da saúde, } \\
\text { palestrante na da } 8 \text { a (NS ("Saúde como direito de todos e dever do estado") }\end{array}$ \\
\hline $\begin{array}{l}\text { Norton de Figueiredo (Ministério da } \\
\text { Educação)* }\end{array}$ & Professor de Clínica de Doenças Infecciosas e Parasitárias da UFRJ \\
\hline Paulo Roberto Teixeira (SES-SP) & Médico dermatologista sanitário, gestor do Programa Estadual de aids de SP \\
\hline Vicente Amato Neto (USP) & Professor de Doenças Infecciosas e parasitárias da USP \\
\hline Walter Belda (USP) & Professor da cadeira de Dermatologia Sanitária da Faculdade de Saúde Pública da USP \\
\hline
\end{tabular}

Fonte: Elaborado pela autora.

Nota: * Norton de Figueiredo era coordenador do programa de aids da UFRJ e não chegou a participar de reuniões da Comissão Nacional. Celso Ferreira Ramos, que trabalhava com ele na UFRJ, como coordenadorexecutivo do programa de aids o substituiu desde a primeira reunião. (PROGRAMA NACIONAL DE DSTEAIDS, 2003)

Entre 1986 e 2001, foram publicadas oito portarias que alteraram a composição e denominação da Comissão, mas mantiveram seus objetivos, adequando-os à estrutura do Ministério da Saúde em cada momento. Em 1994, sofreu uma reformulação e recebeu a denominação pela qual é conhecida até hoje: Comissão Nacional de Aids (Cnaids). (BRASIL, 1986c, 1987, 1988c, 1992, 1994a, 1994b, 1996b, 2000a; PROGRAMA NACIONAL DE DST E AIDS, 2003)

Em 1988, voltaram a figurar na sua composição representantes da sociedade civil organizada, incluindo além do Gapa-SP, outras associações interessadas na epidemia da aids como GGB, Abia, Sociedade Brasileira para o Progresso da Ciência (SBPC), Conselho Nacional de Igrejas Cristãs 
(Conic) e Associação Nacional de Moradores; representantes das universidades; do ministério da saúde; das secretarias estaduais de saúde e do campo médico. (BRASIL, 1988c)

Enquanto instância de assessoramento ao Programa Nacional nas questões técnico-operacionais relacionadas à epidemia da aids, a Cnaids assumiu importante papel na formulação inicial da política, constituindo-se como um grupo de experts no assunto, de diferentes subespaços sociais, que construíam o discurso oficial. (PROGRAMA NACIONAL DE DST E AIDS, 2003) A redação das normas/relatórios era delegada ao médico infectologista Vicente Amato Neto, professor de Doenças Infecciosas Parasitárias da Faculdade de Medicina da USP, apontando mais uma vez para a posição dominante dos médicos nos diferentes subespaços do espaço aids. (E27) No período de 1986, quando foi criada, até 2001, foram realizadas 63 reuniões da Cnaids. (BRASIL, 1994a; PROGRAMA NACIONAL DE DST E AIDS, 2003)

Na primeira gestão de Lair Guerra (1986 a 1989), a discussão dos pontos de pauta resultavam na elaboração de recomendações técnicas que eram adotadas pelo programa ${ }^{72}$ ou na constituição de subcomissões de especialistas para a definição de normas, tendo como base essas recomendações que incluíam membros e não membros da comissão, como no caso da definição dos critérios para uso do AZT. (BOLETIM..., 1988a; BRASIL, 1994a)

A introdução de um dos números do boletim epidemiológico, que traz um documento elaborado pela Comissão Nacional de Controle e Prevenção da Sida/Aids, deixa claro o seu papel na elaboração do discurso oficial:

Os documentos publicados nesse número representam a posição da DIVISÃO NACIONAL DE DST/AIDS-MS sobre direitos humanos e sobre a questão de testes sorológicos para a entrada no País. Qualquer pronunciamento contrário a esta posição é de responsabilidade pessoal do declarante. (RODRIGUES, 1989, p.1)

Por exemplo os documentos "Recomendações sobre o uso de AZT no país" (1994a), posicionamento inicial acerca da "Aplicação de teste anti-HIV para estrangeiros" (1988) e o documento "Crianças e adolescentes em situação de risco" (1989), os dois últimos publicados inclusive no Boletim Epidemiológico Aids. 
Ou seja, naquele período, a Comissão era parte do Estado e teve importante papel técnico e político, assessorando o Programa na definição das estratégias a serem adotadas. (BRASIL, 1994a) Contudo, em outras instâncias governamentais isso nem sempre ocorria, a exemplo da obrigatoriedade da testagem para admissão e nos exames periódicos das forças armadas, que iam contra a orientação ético-legal da comissão. Essa orientação foi revogada em 2001 através de ação civil pública (Portaria n. 12/DGS, de 25 de janeiro de 1989). (PROGRAMA NACIONAL DE DST E AIDS, 2003) De modo que a referida comissão era reconhecida principalmente dentro do espaço aids, o que implicava poder simbólico, mas não fora desse subespaço social.

Para Bourdieu (2012, p. 49, tradução nossa),

A comissão é uma invenção organizacional [...] que consiste em juntar as pessoas de tal maneira que estando organizadas desta forma farão coisas que não fariam se não estivessem assim organizadas..$^{73}$

A comissão produz efeitos simbólicos da entrada em cena do oficial, dá conformidade oficial à representação oficial, elabora uma (nova) definição de um problema público, elabora uma solução, um relatório, que se torna discurso de autoridade. (BOURDIEU, 2012) O meta-poder do Estado materizalizava-se nas resoluções da Cnaids, incorporadas como políticas. Do seu surgimento até o final da primeira gestão de Lair Guerra em março de 1990, foi esse essencialmente o papel da comissão.

Entre os membros da Cnaids havia representação do Conselho Nacional de Igrejas Cristãs (Conic), mas outras instituições das diferentes tradições religiosas também tiveram participação ou influência no espaço aids. semble de telle manière qu'étant organisés de cette façon, ils font des choses qu'ils ne feraient pas s'ils n'étaient pas organisés comme ça." (BOURDIEU, 2012, p. 49) 


\section{O campo religioso e o controle da aids}

Alguns estudos têm analisado a resposta religiosa à epidemia da aids no país, abordando a contribuição das diferentes tradições religiosas. (GALVÃO, 1997; GARCIA et al., 2009; GARCIA; PARKER, 2011; MURRAY et al., 2011) Esse estudo não teve como objetivo abordar os aspectos envolvidos nessa questão, entretanto, tratando-se de uma sociedade na qual a religiosidade e o ecumenismo são bastante presentes e de uma enfermidade relacionada à sexualidade, ao uso de drogas e, do ponto de vista religioso, à transgressão moral, a questão religiosa algumas vezes emergiu nas falas dos entrevistados, denotando a importância de analisar o papel dos agentes desse campo na configuração da política brasileira para controle da epidemia da aids no país, em especial para as estratégias de prevenção.

A análise apresentada nesse tópico foi embasada em alguns fatos históricos identificados nas entrevistas e em análise documental, bem como, revisão bibliográfica sobre o tema resposta religiosa, buscando elucidar a sua interferência na elaboração do discurso oficial.

No Brasil, até a década de 1970, havia uma hegemonia da religião católica entre os brasileiros, que superava o percentual de 90\%, resultado da influência do processo histórico de colonização portuguesa e do status de religião oficial até $1891 .{ }^{74}$ Atualmente, a religião católica continua sendo predominante no país (73,6\% em 2000; 64,6\% em 2010), a despeito da tendência ao crescimento da diversidade de outros grupos religiosos, em especial de evangélicos, que passaram de $15,4 \%$ em 2000 para $22,2 \%$ em 2010. (IBGE, 2012)

No início da epidemia, a inexistência de uma terapêutica eficaz e as características de uma doença fatal tornavam a capacidade de resposta religiosa no nível local, por vezes, maior que a do próprio sistema de saúde, apesar de a doença historicamente ter sido associada ao pecado no discurso religioso.

De acordo com a Constituição Federal de 1891, seção II, artigo 72, §70: “Nenhum culto ou igreja gozará de subvenção oficial, nem terá relações de dependência ou aliança com o Governo da União ou dos Estados." 
Inicialmente, o discurso, em especial da igreja católica, mas também das igrejas pentecostais, relacionava-se à decadência moral, associando a aids a desvios de comportamento, haja vista os principais grupos atingidos pela epidemia - homossexuais, usuários de drogas injetáveis e profissionais do sexo. Esse ponto de vista reforçava o estigma e a discriminação associados aos grupos de risco. A aids era denominada por Dom Eugênio Salles, arcebispo do Rio de Janeiro, como um “castigo divino", como o preço a pagar pelas transgressões cometidas. (GALVÃO, 1997; PARKER, 2009)

Vale lembrar, contudo, que D. Eugênio Salles teve importante papel na viabilização da construção do primeiro laboratório $\mathrm{P}_{3}$ no Brasil, intervindo junto a Camilo Calazans, presidente do Banco do Brasil, para a reconsideração da proposta inicialmente rejeitada pelo responsável pela avaliação do projeto, que possibilitou a criação da rede nacional de laboratórios para isolamento e caracterização do vírus no país.

A CNBB também influenciou as mensagens e a linguagem utilizadas nas campanhas governamentais, como já comentando anteriormente.

Haja vista a proximidade com as populações menos favorecidas e a valorização da caridade e da solidariedade no discurso e na prática religiosos, a principal característica da resposta à epidemia da aids nas diferentes tradições religiosas foi o papel desempenhado na assistência e prevenção, sobretudo voltada para crianças e mulheres, expressas na implantação de casas de apoio e na assistência domiciliar, sendo exemplos a Casa Vida, da Arquidiocese de São Paulo, a Praids, ${ }^{75}$ de orientação protestante, o Centro de Convivência Filhos de Oxum, ligada ao candomblé, ou o grupo ecumênico Associação de Ação Solidária (ASAS), no Recife. (GALVÃO, 1997)

Para as religiões afro-brasileiras, consideradas como mais tolerantes às questões relacionadas à sexualidade, ${ }^{76}$ a aids implicou também na necessidade de novas práticas relacionadas aos rituais, como o uso de

75 A Praids é uma casa para atendimento de doentes com HIV/aids, mantida pela Visão Mundial em convênio com o Centro Evangélico de Apoio à Vida, Ceavi, na zona sul de São Paulo. sileira em geral a rejeição a esse grupo chegava a até 80\%. (MOTT, 1998) 
descartáveis ou a esterilização de instrumentais perfurocortantes utilizados como navalhas, tesouras, lâminas de barbear e outros, e condutas em situações envolvendo soropositividade dos filhos de santo do terreiro, além da formação de multiplicadores. (EPEGA, 1998; GALVÃO, 1997; SILVA, 1998) Muitas ações foram iniciativas de grupos não religiosos como Instituto de Estudos da Religião (Iser), Centro de Referência e Treinamento DST/Aids - São Paulo (CRT-SP) e Grupo Gay da Bahia (GGB). (GALVÃO, 1997)

Assim como nos campos médico, burocrático e no espaço militante, São Paulo também foi pioneiro na resposta religiosa. Em 1987, a Arquidiocese de São Paulo, através do seu arcebispo D. Paulo Evaristo Arns, implantou o Projeto Esperança, que promovia atendimento jurídico, apoio religioso e distribuição de cestas básicas. D. Paulo teve como braço direito nesse Projeto o padre Aníbal Gil Lopes, ${ }^{77}$ também médico e pesquisador, ou seja, a configuração da primeira iniciativa no campo religioso, então, teve como um dos seus principais agentes um padre médico. (GALVÃO, 1997) Ainda que essa não tenha sido uma situação frequente, evidencia mais uma vez a dominância do campo médico no espaço aids.

No campo burocrático, o CRT-SP também incentivou a resposta religiosa, através da criação, em 1988, do Grupo Religioso de Educação, Apoio e Solidariedade, de caráter ecumênico, que buscava definir áreas de atuação e capacitar integrantes das diferentes religiões; e no dia $1^{\circ}$ de dezembro de 1988, dia mundial de combate à aids, 20 líderes religiosos participaram de ato ecumênico na Catedral da Sé, também a partir de uma mobilização promovida pela SES-SP. (GALVÃO, 1997)

O principal conflito entre o discurso do campo burocrático e o campo religioso sempre esteve relacionado ao uso do preservativo, em especial para as religiões de tradição cristã, na qual predominam os conceitos

Filho de uma família de pesquisadores, Aníbal graduou-se médico pela USP em 1973. Ainda durante a graduação resolveu cursar em paralelo o curso de Teologia do Seminário Arquidiocesano de São Paulo. Foi ordenado padre em 1973 com autorização do Papa Paulo VI por não ter cumprido as exigências mínimas para o ingresso oficial na igreja em função da formação em paralelo com o curso de medicina. À época, já era doutor em Fisiologia de Órgãos e Sistemas pela USP (1976) e tinha feito pós-doutorado na área de Biofísica de Processos e Sistemas na Universidade de Yale (EUA). (GAMBOA, 2005) 
relacionados ao campo da moral. Para a igreja, as campanhas que incentivavam o uso do preservativo para prevenção da aids eram um estímulo à promiscuidade sexual. (GALVÃO, 1997; PARKER, 2009)

Estudos têm evidenciado uma divergência entre o discurso oficial da igreja católica, proferido pelas principais autoridades eclesiásticas, condenando ou silenciando as campanhas preventivas que promoviam o uso do preservativo e o respeito às diversidades sexuais e a atuação de alguns de seus agentes, principalmente no nível local. Neste último nível, as lideranças eclesiásticas locais adotavam posições mais flexíveis, semelhante àquela da instituição com a qual a diocese conseguia articular a resposta à epidemia. (MURRAY et al., 2011; PARKER, 2009)

As religiões afro-brasileiras mostravam-se mais receptivas quando se tratava de uso de preservativos. De acordo com o levantamento junto a terreiros de Salvador, realizado pelo Centro Baiano Anti-Aids, os pais e mães de santo entrevistados reconheciam o preservativo (47\%) e a informação (15\%) como melhores formas de proteção, seguidos da prática de sexo seguro, utilização de material perfuro-cortante descartável e esterilizado, ainda que também tenham referido o afastamento dos portadores e a prática da monogamia, em proporções menores; além de em sua maioria (93\%) terem concordado em se tornar centros de prevenção da aids e distribuição de preservativos. (MOTT, 1998)

O fato de Lair Guerra, primeira coordenadora do Programa Nacional de DST/Aids ser batista, pode ter contribuído no enfrentamento ao posicionamento da igreja católica, mantendo a autonomia do Programa e do Estado na elaboração do discurso oficial.

[...] a igreja queria interferir, mas eu acho que foi um momento favorável porque a Lair era batista e a interferência da igreja católica era vista como uma coisa esquisita, protestante e a igreja católica romana. [...] qualquer voz de interferência católica, era mais que a interferência do estado lá, era uma ofensa do ponto de vista da ideologia religiosa. [...] Então isso ajudou sabe, ajudou por que talvez se fosse ao contrário fosse mais aquiescente, né? Já imaginou se fossem os católicos carolas, por exemplo, ia ser muito mais aquiescente à intervenção da igreja católica. [...] (E27) 
Contudo, percebe-se que nem sempre o discurso oficial ficou livre da interferência do campo religioso, em especial da igreja católica, predominante no país, o que pode ser ilustrado pela “censura prévia” imposta à campanha de 1987 pelo Ministro da Saúde que resultou na substituição de termos como "camisa de vênus"e "coito anal", pelos termos "preservativo” e "relação sexual”, por sugestão da CNBB. (PASTORAL..., 1987)

Essa articulação entre agentes de diferentes subespaços foi uma marca da resposta brasileira à epidemia da aids. A complexidade e diversidade das relações estabelecidas, congregando militantes, médicos, religiosos, pesquisadores e burocratas, contribuíram para a complementaridade das diferentes visões, resultando em uma resposta estatal precoce, baseada nos princípios propostos pela Reforma Sanitária Brasileira, embora incipiente e pouco estruturada, principalmente em decorrência das possibilidades terapêuticas da época e da estrutura do Sistema Único de Saúde que começava a ser implantado. A criação de novas instituições especializadas naquele primeiro momento, como associações de luta contra a aids, estruturas administrativas especializadas - programas estaduais, programa nacional -, centros de aconselhamento e testagem e centros de referência, bem como o estabelecimento de grupos de experts, em suas respectivas áreas, foram fundamentais para a consolidação da política nacional no período seguinte (1990-2001), com a adoção de medidas de vanguarda para um país em desenvolvimento. 